\title{
The effects of income distribution and fiscal policy on aggregate demand, investment and the budget balance: the case of Europe
}

\begin{abstract}
This paper develops a multi-country post-Kaleckian model that incorporates the role of the government. One key novelty of the model is that it integrates cross-country effects of both changes in income distribution and fiscal policy. The model is used to estimate econometrically the effects of income distribution and fiscal policy on the components of aggregate demand and the budget balance in EU15 countries. The results show that a simultaneous increase in the wage share in all EU15 countries would increase demand and the primary budget balance in all countries. A simultaneous increase in government spending turns out to boost economic activity in all the EU15 countries, indicating the positive economic effects of expansionary fiscal policy. Moreover, a progressive tax policy that would be implemented simultaneously at the EU level would lead to an increase in output in all countries.
\end{abstract}

Keywords: Wage Share, Fiscal Multiplier, Demand Regime, Fiscal Policy JEL codes: E12, E25, E62 


\section{Introduction}

The outbreak of the Great Recession and the sluggish growth in the aftermath in most European countries has rekindled interest in the effect of fiscal policy on economic activity, as evidenced in the vast literature on fiscal multiplier effects (Blanchard and Leigh, 2013; Gechert, 2015). Although it has been shown that austerity policies have negative effects on output and private investment, contributing to the prolonged stagnation in Europe, fiscal contraction continues to be the dominant European strategy in the post-crisis era.

At the same time, inequality has increased significantly since the 1980s in all the major developed and developing countries with a simultaneous fall in the share of labour income in national income and a rise in top income shares (Stockhammer, 2017). The negative impact of inequality on growth has been well evidenced in empirical research based on both supply-side growth models (Barro, 2000; Daudey and Garcia-Penalosa, 2007; Berg et al., 2012) and postKeynesian demand-led growth models (Naastepad and Storm, 2006; Hein and Vogel, 2008; Stockhammer et al., 2009; Onaran and Galanis, 2014; Onaran and Obst, 2016).

However, the combined effects of fiscal policy and income distribution on economic activity and fiscal performance have not yet been empirically investigated in the context of models with demand-led output. So far, these models, most of which place particular emphasis on functional income distribution, have been used to explore various effects of fiscal policy at a theoretical level. In particular, within a closed economy framework, Blecker (2002:129-141), Mott and Slattery (1994) and Palley (2014) have focused on the interactions between tax policies, output and income distribution. Mott and Slattery (1994) have studied the effects of taxes on income distribution and output, paying particular attention to the role of tax shifting, while Blecker (2002:129-141) and Palley (2014) have analysed how different tax rates on labour and capital income affect whether the growth regime of an economy is wage-led or profit-led. You and Dutt (1996), Zezza and Dos Santos (2004), Palley (2013), Ryoo and Skott (2013), Allain (2015), Hein (2016), Kapeller et al. (2017), Ko (2018) and Ribeiro and Lima (2018) have studied the effects of aggregate government expenditure on various macroeconomic variables, such as output, capital accumulation and public debt. In similar lines, Commendatore et al. (2011), Seguino (2012), Dutt (2013), Tavani and Zamparelli (2017) have focused on the effects of different types of government expenditure. Yoshida and Asada (2007), Charpe et al. (2011) and Nikolaidi (2014) have analysed the role of counter-cyclical fiscal policy, focusing on its positive stabilising effects.

Within an open economy framework, Blecker (1999; 2002:141-145) and GreenwoodNimmo (2014) have analysed the various interactions between government spending, taxation 
and income distribution. However, these models do not consider the cross-country spill over effects of the joint effects of income distribution and fiscal policy. Thus, they do not permit a more integrated approach to the way that government spending, taxation and income distribution interact when trade relationships are incorporated in the analysis.

The novelty of this paper is twofold. First, we develop a post-Kaleckian theoretical model that incorporates the role of the government within an open economy context. The model moves beyond the above-mentioned literature because it is a multi-country model that allows the analysis of the interactions between countries. Second, we use this model in order to estimate econometrically the effects of income distribution and fiscal policy on the components of aggregate demand (AD) for each of the EU15 countries. ${ }^{1}$ We calculate a Europe-wide multiplier based on the responses of each country to changes in not only domestic but also other European countries' income distribution, taxation and government spending. Hence, we move beyond Onaran and Galanis (2014) and Onaran and Obst (2016) who presented the impact of simultaneous changes in income distribution in the G20 and the EU15, but did not incorporate the impact of public spending and taxes. From a policy perspective, the analysis of the paper can guide the development of a fiscal and wage policies conducive to higher economic activity in the short run.

The rest of the paper is organised as follows. Section 2 outlines the theoretical model. Section 3 presents the data and describes the estimation methodology. Section 4 presents the estimation results. Section 5 examines the effects of wage and fiscal policies on output, private investment and the primary budget balance. Moreover, it compares the effects when policies are implemented in one country in isolation versus the case in which policies are implemented simultaneously in all countries. Finally, section 6 summarises and concludes.

\section{A post-Keynesian/post-Kaleckian macro model with government}

\subsection{Structure of the model}

Our multi-country model for the EU15 countries is based on the post-Kaleckian framework (see Bhaduri and Marglin, 1990). We integrate fiscal policy (tax rates and government expenditure) into the private sector open economy model presented in Onaran and Galanis (2014) and Onaran and Obst (2016) and formalise the effects of a change in the profit share and fiscal policy by means of analysing the country-level effects on private aggregated demand: consumption, investment, exports and imports. We then simulate European interactions through integrating the effects of a change in income distribution as well as fiscal policy of other EU15 countries. 
Our model is designed to capture short-run effects. This implies that we abstract from endogenous changes in income shares, labour productivity and capital stock as well as from the dynamic stock-flow interaction between public debt, private financial assets/liabilities and economic activity. The incorporation of these issues would require the development of a much more complicated model, which moves beyond the scope of the current paper. Compared to a more complicated long-run model, the main advantage of our relatively simple short-run model is that, as will be shown below, it permits us to identify the exact channels through which wage and fiscal policy affect aggregate demand.

Consumption $(C)$ is given by:

$$
\log C=c_{0}+c_{r} \log \left(1-t_{r}\right) R+c_{w}\left(\log \left(1-t_{w}\right) W+\log S\right)
$$

where $R$ denotes profits, $W$ stands for wages, $t_{r}$ denotes the tax rate on capital income, $t_{w}$ stands for the tax rate on labour income and $S$ denotes the social transfers in cash. Note that after-tax profits are equal to $R^{\prime}=\left(1-t_{r}\right) R$ and after-tax wages are given by $W^{\prime}=$ $\left(1-t_{w}\right) W$. Compared to Onaran and Obst (2016), consumption function (1) has two new features: first, it includes tax rates on capital income and tax rates on labour income; second, it incorporates social transfers, which augment the disposable income of households. Previous demand-led growth models have used consumption functions with different tax rates on wage income and capital income (see e.g. Mott and Slattery, 1994; You and Dutt, 1996; Blecker, 2002; Palley, 2014; Ko, 2018; Ribeiro and Lima, 2018). However, the consumption functions in these models do not include social transfers. We hypothesise that a more progressive tax system (which in this paper is captured by an increase in taxes on capital and a decrease in taxes on labour) supports a wage-led economic regime, whereas a more regressive tax system would boost economic activity in a profit-led regime.

Private investment $(I)$ is modelled based on the following specification:

$$
\log I=i_{a}+i_{y} \log Y_{p}+i_{\pi} \log \left(1-t_{r}\right) \pi+i_{g} \log G+i_{r} r
$$

where $i_{a}$ is autonomous investment and captures the effects of 'animal spirits', $Y_{p}=Y-G$ denotes private demand, defined as GDP $(Y)$ minus the government expenditure that is part of GDP $(G), \pi$ denotes the profit share and $r$ is the interest rate. Note that the after-tax profit share is equal to $\pi^{\prime}=\left(1-t_{r}\right) \pi$. This specification implies that private investment is affected by four factors. First, a higher level of aggregate demand is assumed to increase private investment. This is a standard assumption in the related empirical literature (e.g. Hein and Vogel, 2008; Stockhammer et al., 2009; Onaran and Galanis, 2014). Second, in line with the post-Kaleckian literature that draws on Bhaduri and Margin (1990), investment depends on the profit share, (e.g. You and Dutt, 1996; Hein, 2007; Hein and Vogel, 2008; Stockhammer et al., 2009; 
Seguino, 2012; Onaran and Galanis, 2014; Onaran and Obst, 2016). We assume that firms consider after-tax profits in making investment decisions as widely assumed in the literature (e.g. You and Dutt, 1996; Blecker, 2002; Seguino, 2012).

Third, following Kapeller et al. (2017), private investment is assumed to be positively affected by total government spending. As explained below, this allows us to examine potential crowding-in effects that might stem from the fact that government expenditure can improve business environment. ${ }^{2}$ Fourth, we include the impact of interest rate on investment in order to take into account the negative impact that the cost of borrowing might have on investment (see also Taylor, 1985; Onaran and Galanis, 2014; Onaran and Obst, 2016). Based on the above, in the empirical estimations we overall expect $i_{y}>0, i_{\pi}>0, i_{g}>0$ and $i_{r}<0$.

Our investment function assumes that investment spending depends on the profit share. An alternative assumption would be to postulate that investment relies on the profit rate (e.g. Rowthorn, 1981; Dutt, 1984; Taylor, 1985; van Treeck, 2009; Carvalho and Rezai, 2016; Tavani and Zampareli, 2017). However, this would increase the sensitivity of investment to changes in capacity utilisation, relative to changes in profitability: Bhaduri and Marglin (1990) have argued that since the profit rate can be decomposed into capacity utilisation and the profit share, the inclusion of both variables in the investment function would account for the impact of capacity utilisation on investment twice. Moreover, as shown by Blecker (2002), the inclusion of the profit rate instead of the profit share in the investment function would increase the possibility of obtaining a wage-led demand regime. In our case, we prefer to use a specification that does not reduce the possibility of obtaining a profit-led demand regime. However, this does not mean that the post-Kaleckian investment function is necessarily superior to an investment function that would use the profit rate as an independent variable. For example, it could be argued that in practice firms make their investment decisions based on the profit rate. $^{3}$

In order to integrate the effects of expansionary fiscal policy on demand in the EU15 we define government expenditure as a fraction of GDP: ${ }^{4}$

$$
G=\kappa_{g} Y
$$

The total primary government expenditure $\left(G_{t o t}\right)$ is equal to:

$$
G_{\text {tot }}=G+S
$$

Taxes $(T)$ are given by:

$$
T=t_{w} W+t_{r} R+t_{c} C
$$

where $t_{c}$ is the tax rate on consumption.

The primary budget balance of the government sector $(P B)$ is: 


$$
P B=T-G_{t o t}
$$

GDP is given by:

$$
Y=C+I+G+N X
$$

where net exports $(N X)$ is equal to exports $(X)$ minus imports $(M)$.

We model the effects of distribution on net exports using a stepwise approach that follows Stockhammer et al. (2009), Onaran et al. (2011), and Onaran and Galanis (2014). We extend the specification of domestic and export prices by including tax rate on consumption at home and abroad. Domestic prices $(P)$ and export prices $\left(P_{x}\right)$ are determined as follows:

$$
\begin{gathered}
\log P=p_{0}+p_{u l c} \log (u l c)+p_{t c} \log \left(1+t_{c}\right)+p_{m} \log P_{m} \\
\log P_{x}=p_{x 0}+p_{x u l c} \log (u l c)+p_{c f} \log \left(1+t_{c f}\right)+p_{x m} \log P_{m}
\end{gathered}
$$

where $u l c$ denotes nominal unit labour costs, $P_{m}$ stands for import prices and $t_{c f}$ denotes tax rate on consumption abroad. Compared to Onaran and Obst (2016), we have taken into account that the tax rate on consumption might increase domestic and export prices.

Exports are given by:

$$
\log X=x_{0}+x_{p x m} \log \left(P_{x} / P_{m}\right)+x_{y r w} \log Y_{r w}+x_{e} \log E
$$

where $Y_{r w}$ is the GDP of the rest of the world and $E$ is the exchange rate. Exports are a function of relative prices of exports to imports, the GDP of the rest of the world and exchange rate.

Imports are equal to:

$$
\log M=m_{0}+m_{p p m} \log \left(P / P_{m}\right)+m_{y} \log Y_{p}+m_{g} \log G+m_{e} \log E
$$

Imports depend on domestic prices relative to import prices, the exchange rate and aggregate demand in which we include separately $Y_{p}$ and $G$ (Palley, 2009).

2.2 Effects of a change in the profit share and fiscal policy on aggregate demand, private investment and primary budget balance

The model presented above can be deployed to study the short-run effects of a change in profit share $(\pi)$ and fiscal policy on aggregate demand, private investment and primary budget balance as a ratio to output (the algebraic details are reported in Appendix A). An increase in $\pi$ has both first-round and second-round (post-multiplier) effects on aggregate demand as illustrated in Figure 1 and Figure 2. An increase in $\pi$ tends to reduce consumption since the propensity to consume out of wages is expected to be higher than the propensity to consume out of profits. Investment is positively affected since an increase in $\pi$ raises the expected profitability and the 
availability of internal finance for a given capacity utilisation. Net exports tend to increase since the export and domestic prices decline because of the reduction in the unit labour cost caused by the increase in $\pi$. These are the first-round effects (see Figure 1). If the positive effects on demand prevail over the negative ones, we have a profit-led demand regime. In the opposite case, the demand regime is wage-led.

\section{Figure 1}

At a second stage, the change in output, that stems from the rise in $\pi$, influences the components of demand through the multiplier effects. In Figure 2, we illustrate these multiplier effects when an exogenous shock leads to a rise in output (these channels work in the opposite direction if the shock leads to a decline in output, i.e. in a wage-led demand regime). When we have a profit-led demand regime, an increase in $\pi$ increases output which in turn (i) increases consumption since households' disposable income goes up, (ii) increases private investment since the sales of firms go up, (iii) decreases net exports since higher output might induce firms and the government to buy more goods and services from foreign countries and (iv) increases government expenditure since government spending is proportional to output.

\section{Figure 2}

Regarding the effects of $\pi$ on the primary budget balance-to-GDP ratio, we also have both first-round and second-round effects. In the first-round an increase in $\pi$ leads to an increase in the revenues collected from taxes on capital income and a decrease in revenues collected from taxes on consumption and wage income. At a second stage (and in a profit-led demand regime), the rise in $\pi$ causes an increase in output that increases both government spending and tax revenues since both of them are a positive function of output. Hence, the overall effects on the primary balance are ambiguous.

Furthermore, we focus on the effects of the following changes in fiscal policy: (i) an increase in government expenditure-to-GDP ratio $\left(\kappa_{g}\right)$, (ii) an increase in the tax rate on capital income $\left(t_{r}\right)$, (iii) a decrease in tax rate on labour income $\left(t_{w}\right)$ and (iv) a combination of a progressive tax policy based on a fall in the tax rate on wages and an increase in the tax rate on profits.

The increase in government spending is captured by a rise in $\kappa_{g}$. The related channels are shown in Figure 3. At a first stage, the increase in $\kappa_{g}$ leads to lower net exports since the government may buy goods and services from abroad. ${ }^{5}$ A rise in $\kappa_{g}$ has a positive effect on private investment since it increases the sales of firms and might improve the business environment. However, since the rise in $\kappa_{g}$ stimulates output, we also have second-round effects on aggregate demand as already shown in Figure 2. 
We now turn to the effects of tax policies as shown in Figure 4. An increase in $t_{r}$ affects consumption and investment directly. Consumption decreases since after-tax profits decline. Investment is adversely affected by lower after-tax profits. Overall, the increase in $t_{r}$ negatively affects aggregate demand. The effect of a higher in $t_{r}$ on primary budget balance is ambiguous since there is a decrease in the revenues collected from taxes and a simultaneous decrease in government expenditure. Similar channels apply when $t_{w}$ decreases. When an increase in $t_{r}$ is combined with a decrease in $t_{w}$, the overall effects on consumption and investment are ambiguous.

\section{Figure 4}

All the effects mentioned above refer only to changes that are implemented in countries individually. However, drawing on Onaran and Obst (2016), our model can be applied to analyse the effects associated with changes that take place simultaneously in the EU countries. This is particularly important because of the high integration of the European economies. The related calculations are reported in Appendix B.

\section{Data and estimation methodology}

The data used in the econometric estimation refers to EU15 countries and mostly comes from the annual macro-economic database of the European Commission (AMECO) and the OECD national accounts, in most cases for the period between 1960 and 2013. The tax rates are based on Eurostat data for most countries for the period of 1965-2012. For the estimation of our investment function we use the real long-term interest rate that captures the cost of borrowing for the government. Although the proper interest rate is the lending interest rate of firms (which refers to firms' access to credit), there is a lack of sufficiently long time series data for this variable. Therefore, we have used instead the real long-term interest rate, which is a good proxy of the firm lending interest rate (we have found that the correlation between the two interest rates is high in the vast majority of the countries). ${ }^{6}$ The definitions of all variables and sources can be found in Appendix C. ${ }^{7}$

In our econometric estimations, we focus only on the components of government expenditure that are part of GDP. These are the gross capital formation $\left(I_{g}\right)$, the individual consumption expenditure $\left(G_{i}\right)$, and the collective consumption expenditure $\left(G_{c}\right)$ of the general government. On average, $G_{i}, G_{c}$ and $I_{g}$ constitute roughly 50 per cent of total government expenditure in our sample. An important part of the remaining government expenditures are social transfers in cash. These have been included in our theoretical model (see section 2) but not in our empirical estimations due to limited data availability (e.g. social benefits in cash start 
only in 1995 for most EU15 countries). Moreover, in our econometric estimations we include only the tax revenues, which are the biggest part of government revenues, leaving aside other revenue streams such as property income or national insurance payments.

Despite the fact that our model is a short-run one, we need to rely on long time-series in order to estimate our parameters in a statistically credible way. However, it is important to point out that these estimates capture the average behaviour of the economies in the period under investigation. For example, if an economy appears to be wage-led based on the parameter estimations for the whole period, this does not necessarily mean that this has been the case for all the sub-periods. As pointed out by Nikiforos (2016), there might have been sub-periods in which the economies have been profit-led and other sub-periods whereby the economies have been wage-led. However, if our estimated coefficients imply that an economy is wage-led for the whole period, this implies that this economy has been on average wage-led in the period under investigation and this is the best estimation that we can use for our short-run parameters.

We estimate separate single equations for consumption, investment, exports, imports, domestic prices and export prices. We choose the single equation approach (SEA) because it allows a clearer interpretation of the results and permits us to deal with the fact that the time period of our sample is quite short. However, the main limitation of the SEA approach is that it might introduce some bias resulting from endogeneity issues, which might arise from the fact that the wage share and the government expenditure-to-GDP ratio are arguably a function of output. These could be tackled by using a VAR or an instrumental variable method. However, as discussed in Onaran and Obst (2016), these methods have their own limitations. Most importantly, it is necessary to have a large number of observations, which is not the case in our sample. Hence, we have chosen to use a SEA approach, which is also in line with the fact that our model is a short-run one, and we have reasonably assumed that the time lag of the impact of output on distribution and government expenditure is longer than one year.

Unit root tests suggest that most of our variables are integrated of order one. ${ }^{8}$ The profit share is stationary in Greece, Spain, Sweden and the UK. Hence, we use this variable in its level in these countries. We first estimate error-correction models (ECM). If no cointegration is found, the equations are estimated in differences. We start with general specifications and only keep those variables, which are statistically significant. In order to test for autocorrelation we use the Breusch-Godfrey test. In the case of autocorrelation, either we keep the lagged dependent variable or add an AR(1) term. As outlined in Onaran and Obst (2016), we derive the long-term coefficients (elasticities) using two different methods depending on whether there is a short-run (differenced form) or a long-run relationship (ECM) among the variables. 


\section{Estimation results}

The estimation results for our consumption function (equation 1) are given in Table 1. The hypothesis that the marginal propensity to consume (MPC) out of profit income is larger than the propensity to consume out of wage income is confirmed in all countries.

\section{Table 1}

Table 2 presents the effects on private investment based on equation (2). We find strong and significant accelerator effects of private demand on private investment in all countries. Regarding the after-tax profit share, the effects are more varied. The profit share has no statistically significant effect in 10 countries: Austria, Belgium, Denmark, Finland, Germany, Greece, Luxemburg, Portugal, Spain and the UK. ${ }^{9}$ In these cases, the effects are treated as zero when we calculate the total effects on excess demand. There is a positive statistically significant effect of government expenditure in 7 EU countries: Denmark, Finland, Germany, Greece, Ireland, the Netherlands, and Portugal. There are only two countries (Belgium and France) where the effects of government expenditure on private investment are negative. ${ }^{10} \mathrm{We}$ find significant negative effects of an increase in long-term interest rate on private investment in only two countries: Denmark and Sweden.

\section{Table 2}

The estimation results for domestic prices, export prices, exports, and imports are reported in Tables 3 to 6 . The results are broadly in line with our expectations; however, there are no significant effects of export prices relative to import prices on exports in Belgium, Ireland, Luxembourg, the Netherlands and Portugal. We also find no statistically significant effects of domestic prices relative to import prices on imports in Denmark, Finland, Germany, Greece, Luxembourg, and the UK. An increase in government expenditure leads to an increase in imports in 6 countries: Belgium, Germany, Ireland, Portugal, Sweden, and the UK. Regarding the tax rate on consumption, we find statistically significant effects on domestic prices in 7 countries: Finland, Ireland, Italy, Portugal, Spain, Sweden, and the UK. Concerning export prices, we find statistically significant effects in only 3 countries: Denmark, Germany and Italy.

\section{Table 3}

Table 4

\section{Table 5}

\section{Table 6}

We have run a series of robustness checks for consumption and investment estimations. ${ }^{11}$ For consumption, we have checked the robustness of our results using different sample sizes: 
1960-2007; 1980-2007; 1980-2012. Our results are robust except for Spain. Here, we find either insignificant or perverse effects of profit income on consumption for the full sample, which is at odds with our previous estimations and the empirical literature (Onaran and Obst, 2016). ${ }^{12}$ Hence, we have kept the full sample for all EU15 countries, but Spain, where estimation is based on the pre-crisis period. In the case of investment, the results are robust if we estimate specification 2 for the pre-crisis period of 1960-2007.

\section{Effects of wage and fiscal policies}

Using our econometric estimations, we simulate the effects of a 1\%-point decrease in the profit share $(\pi)$ on aggregate demand, private investment, and primary budget balance (policy 1; see Appendices A and B for details). We consider both the case in which this decrease takes place only in one country individually and the case in which the profit share decreases in all countries in the EU15 simultaneously.

Table 7 presents the results. Column A reports how excess demand changes as a response to an individual decline in the profit share of a country, which is the sum of the partial effects of the profit share on consumption, investment, government expenditure and net exports as a ratio to GDP. These partial effects are presented in Appendix D (note that the government expenditure/GDP does not change when $\pi$ declines). Three points are worth mentioning. First, in the majority of countries the positive partial effects of a decrease in $\pi$ on consumption are higher in comparison with the results presented in Onaran and Obst (2016). This is explained by the incorporation of tax rates in the model, which tends to increase the differences in the propensities to consume out of wages and profits. Second, the partial effect on investment of an increase in $\pi$ is either positive or statistically insignificant. Third, all countries exhibit a wage-led demand regime. Interestingly, incorporating the effects of $\pi$ on net exports does not change the nature of the demand regime compared to the domestic demand regime.

\section{Table 7}

Column B reports the multipliers, which capture the second-round effects of the change in demand induced by the decline in $\pi$. With the exception of Belgium and Luxemburg, the multipliers are above one and range between 1.13 (Ireland) and 4.84 (Netherlands). ${ }^{13}$ In comparison to the multipliers estimated in Onaran and Obst (2016), where fiscal policy was not taken into account, the multipliers reported in Table 7 are higher for all countries. Note that the incorporation of fiscal policy tends to increase the multiplier because a rise in output increases $G$ (since $\kappa_{g}$ is fixed) and private investment. However, it also tends to decrease the multiplier because a rise in $G$ increases imports. 
Column $\mathrm{C}$ shows the effects of a 1\%-point fall in $\pi$ on demand and output after the multiplier effects. The countries in which the positive demand effects of a decline in $\pi$ are strongest are Greece, Spain and Germany.

Most importantly, when the decline in $\pi$ takes place in all countries simultaneously (Column G), the growth effects are reinforced. Overall, a simultaneous decline in the profit share in all countries leads to an increase in the EU15 GDP by $1.41 \% .^{14}$

Column D refers to private investment. A $1 \%$ fall in $\pi$ improves private investment in the majority of EU15 countries (with the exception of Ireland and Italy). When this fall takes place in all countries simultaneously (Column $\mathrm{H}$ ), private investment improves in all countries but Ireland. On average, private investment in the EU15 increases by $0.36 \%$-points as a ratio to GDP.

A fall in $\pi$ leads to an improvement in the primary budget balance (as a proportion of output) in all countries (Column E) except the UK. Since the EU15 countries exhibit a wage-led regime, a fall in $\pi$ leads to a collection of more tax revenues (both directly and indirectly) that is quantitatively more significant than the increase in government expenditure. This holds because the government is able to collect more taxes from higher consumption expenditure and higher wage income. In the UK there is a deterioration in the primary budget balance because there is a large drop in tax revenues from capital income that is not counterbalanced by the increase in tax revenues from wage income and consumption.

The positive effects of $\pi$ on the primary budget balance are reinforced when $\pi$ declines simultaneously in all countries (Column I). A $1 \%$-point simultaneous fall in $\pi$ leads to an improvement in the primary budget balance of all countries (including the UK) due to the fact an increase in the wage share has positive effects on GDP. The effects range from $0.02 \%$-points (UK) to $0.6 \%$-points (Spain).

Finally, we analyse the extent to which a wage stimulus in the EU15 countries would exert price effects. Prices increase by roughly $1.3 \%$ following an isolated decline in $\pi$ by $1 \%$-point (Column F) and by $1.5 \%$ if $\pi$ declines simultaneously in all countries (Column J). Hence, the rise in prices because of a wage stimulus is quite moderate.

We now turn to the effects of fiscal policy. Policy 2 captures the increase in the government expenditure-to-GDP ratio $\left(\kappa_{g}\right)$ by $1 \%$-point. The effects of this policy are presented in Table 8 . An increase in $\kappa_{g}$ in each country individually increases GDP significantly. As shown in Column C, the effect ranges from roughly $0.01 \%$ (Belgium) to $8.83 \%$ (Netherlands). The effects become much more positive when all countries increase government expenditures 
simultaneously (Column F). This is due to high cross-country spill-over effects. ${ }^{15}$ Overall, the EU15 GDP increases by $3.29 \%$.

\section{Table 8}

An increase in government expenditure also leads to a rise in private investment in all countries apart from Belgium and France where the direct effects of government spending on investment are negative (Column D). Again, the effect is stronger when fiscal policy is implemented in coordination as opposed to the case in which it is implemented in isolation. This is the reason why a simultaneous fiscal expansion increases investment in France despite the fact that the direct effect of government spending on investment is negative (Column $G$ ). However, as shown in Column E, a $1 \%$-point increase in $\kappa_{g}$ leads to a deterioration of the primary budget in almost all countries (the only exception is the Netherlands in which the multiplier is high). The reduction ranges from $0.38 \%$-points (Finland) to $0.99 \%$-points (Belgium). This reduction is, however, lower when government spending increases in all countries simultaneously (see Column H). In the Netherlands the budget balance improves by $0.63 \%$-points.

Policy 3 refers to a $1 \%$-point increase in the tax rate on capital income $\left(t_{r}\right)$. Its effects are reported in Table 9. As a result of an isolated rise in $t_{r}$, output decreases in all countries (Column C). This reduction is slightly stronger when $t_{r}$ increases simultaneously in all countries. Overall, EU15 GDP would decrease by $0.31 \%$ (Column F). As expected, a higher $t_{r}$ reduces consumption and private investment and improves the primary budget balance (see Columns $\mathrm{G}$ and $\mathrm{H}$ ).

\section{Table 9}

Table 10 shows the effects of policy 4, which captures a 1\%-point decrease in tax rate on labour income $\left(t_{w}\right)$. This policy has a significant positive effect on consumption, which leads to both higher output and private investment. When it is implemented simultaneously in all countries, it causes, on average, an increase in the EU15 GDP by 1.53\% (Column F) and an increase in the EU15 private investment by $0.44 \%$-points (Column G). Interestingly, the primary budget balance improves as a result of policy 4 (Columns $\mathrm{E}$ and $\mathrm{H}$ ). The strong positive effects on consumption result in a significant increase in the revenues that come from the taxation of consumption. This counterbalances the decrease in the taxes on labour.

\section{Table 10}

Table 11 presents the effects of a progressive tax policy (Policy 5) based on a combination of a $1 \%$-point increase in the tax rate on profits (Policy 3 ) and a $1 \%$-point fall in the tax rate on wages (Policy 4). The positive effects of a fall in the tax rate on labour income on 
consumption outweigh the negative effects of a rise in the tax rate on capital income on consumption as well as private investment. All countries experience positive effects with values ranging between $0.43 \%$ (Ireland) and 3.44\% (Netherlands). Overall, EU15 GDP increases by $1.22 \%$ (Column F).

\section{Table 11}

\section{Conclusion}

This paper constructed a short-run empirical post-Kaleckian model for EU15 countries and the results were used to examine the effects of wage and fiscal policies on aggregate demand, investment and budget balance.

The empirical analysis has shown that a simultaneous decline in the wage share in a highly integrated European economy leads to a decline in economic activity. There is room to stimulate demand in an economic climate of sluggish demand: a 1\%-point simultaneous increase in the wage share at the European level could lead to an increase in EU15 GDP by $1.41 \%$.

The negative effects of a fall in the wage share on consumption overpower the positive effects on investment in 15 European countries. When considering after-tax income, the differences in marginal propensity to consume out of wage versus profit income are significantly larger in the majority of the EU15 countries, compared to the previous empirical literature. Moreover, the general breakdown of the profit-investment nexus becomes even more apparent, when investment is estimated as a function of after-tax profits. Hence, domestic demand is clearly wage-led in the EU15. Interestingly, integrating the foreign sector does not lead to a change in the impact of distribution on demand since domestic demand is strongly wage-led. Therefore, in isolation, without the international spill-over effects, we find all countries to be wage-led.

The fiscal expansion has beneficial effects on aggregate demand in all EU15 countries and leads to higher private investment in almost all of them. In addition, the hypothesis that a more progressive tax system (e.g. a redistributive tax policy based on a 1\%-point fall in the tax rate on wages and a $1 \%$-point increase in the tax rate on capital) potentially stimulates demand is confirmed by our empirical estimations. The positive effects of a reduction of the tax rate on wages significantly induce consumption and thus outweigh the negative effects on investment spending (and consumption demand) due to an increase in the taxation of profit income.

As an outcome of a wage-led recovery scenario, the majority of the countries would experience increasing prices but by well below $2 \%$. This implies that if the inflation rate were initially close to $0 \%$, a wage stimulus in the EU15 would not lead to an inflation rate higher 
than the ECB target inflation rate of $2 \%$. In fact, it would help keep the European economy away from deflation.

Drawing on our results, it could be argued that a policy mix that would combine a prolabour wage policy, an increase in government spending and a more progressive tax system would increase output in the EU15 countries significantly. Due to the positive spill-over effects on demand, this effect would be even more significant if this policy mix would be implemented in a coordinated fashion across Europe. Furthermore, it is very likely that such a policy mix would improve the primary budget balance because of the positive effects of higher economic activity on tax revenues.

The econometrically estimated model in this paper has been kept quite simple to illuminate the key channels through which income distribution and fiscal policy interact in a demand-led economy. Future extensions of the model could move beyond the short-run nature of our analysis by incorporating the long-run dynamics of labour productivity, capital accumulation, private debt, employment and public debt. In addition, future empirical research could investigate how the combination of wage and fiscal policy could be used to achieve social and environmental targets, such as gender equality and low carbon emissions. 


\section{References}

Allain, O. 2015. Tackling the instability of growth: a Kaleckian-Harrodian model with an autonomous expenditure component, Cambridge Journal of Economics, vol. 39, no. 1, 13511371

AMECO 2016. Annual macro-economic database of the European Commission, http://ec.europa.eu/economy_finance/ameco/user/serie/SelectSerie.cfm, last accessed 16 November 2017

Auerbach, A. J. and Gorodnichenko, Y. 2013. Output spillovers from fiscal policy, The American Economic Review, vol. 103, no. 3, 141-146

Barro, R. J. 2000. Inequality and growth in a panel of countries, Journal of Economic Growth, vol. 5, no. 1, 5-32

Berg, A., Ostry, J. D. and Zettelmeyer. J. 2012. What makes growth sustained? Journal of Development Economics, vol. 98, no. 2, 149-166

Blanchard, O. J. and Leigh, D. 2013. Growth forecast errors and fiscal multipliers, American Economic Review, vol. 103, no. 3, 117-120

Blecker, R. A. 1999. Kaleckian macro models for open economies, pp. 116-149 in Deprez, J. and Harvey, J. T. (eds.) Foundations of International Economics: Post Keynesian Perspectives, London, Routledge

Blecker, R. A. 2002. Distribution, demand, and growth in neo-Kaleckian macro models, pp. 129-152, in Setterfield, M. (ed.) The Economics of Demand-Led Growth: Challenging the Supply-Side Vision of the Long Run, Cheltenham, UK and Northampton, MA, Edward Elgar

Carvalho, L., and Rezai, A. 2016. Personal income inequality and aggregate demand. Cambridge Journal of Economics, vol. 40, no. 2, 491-505

Charpe, M., Chiarella, C., Flaschel, P. and Semmler, W. 2011. Financial Assets, Debt and Liquidity Crises, New York, Cambridge University Press (Chapter 9)

Commendatore, P., Panico, C. and Pinto, A. 2011. The influence of different forms of government spending on distribution and growth, Metroeconomica, vol. 62, no. 1, 1-23

Daudey, E. and Garcia-Penalosa. C. 2007. The personal and the factor distributions of income in a cross-section of countries, Journal of Development Studies, vol. 43, no. 5, 812-829

Dutt, A. K. 1984. Stagnation, income distribution and monopoly power, Cambridge Journal of Economics, vol. 8, no. 1, 25-40

Dutt, A. K. 2013. Government spending, aggregate demand, and economic growth, Review of Keynesian Economics, vol. 1, no. 1, 105-119

European Commission 2000. Structures of the taxation systems in the European Union 19701997, Brussels, European Commission

Eurostat 2015. Database online Your key to European statistics, http://ec.europa.eu/eurostat/data/database, last accessed 16 November 2017

Gechert, S. 2015. What fiscal policy is most effective? A meta-regression analysis, Oxford Economic Papers, vol. 67, no. 3, 553-580

Gollin, D. 2002. Getting income shares right, Journal of Political Economy, vol. 110, no. 2, $458-474$

Greenwood-Nimmo, M. 2014. Inflation targeting monetary and fiscal policies in a two-country stock-flow-consistent model, Cambridge Journal of Economics, vol. 38, no. 4, 839-867

Gruber, J. W. and Kamin, S. B. 2012. Fiscal positions and government bond yields in OECD countries, Journal of Money, Credit and Banking, vol. 44, no. 8, 1563-1587

Hein, E. 2007. Interest rate, debt, distribution and capital accumulation in a post-Kaleckian model, Metroeconomica, vol. 58, no. 2, 310-339

Hein, E. 2016. 'Autonomous Government Expenditure Growth, Deficits, Debt and Distribution in a Neo-Kaleckian Growth Model', IPE Working Paper Series no. 68/2016

Hein, E. and Vogel, L. 2008. Distribution and growth reconsidered: empirical results for six OECD countries, Cambridge Journal of Economics, vol. 32, no. 3, 479-511 
Kapeller, J., Landesmann, M. A. Mohr, F. X., and Schütz, B. 2017. Government policies and financial crises: mitigation, postponement or prevention?, Cambridge Journal of Economics, vol. 42, no. 2, 309-330

Kinoshita, N. 2006. 'Government Debt and Long-Term Interest Rates', IMF Working Paper no. $06 / 63$

Ko, M.C., 2018. Fiscal policy, government debt, and economic growth in the Kaleckian model of growth and distribution, Journal of Post Keynesian Economics, 1-17

Mendoza, E. G., Milesi-Ferretti, G. and Asea, P. 1997. On the ineffectiveness of tax policy in altering long-run growth: Harberger's superneutrality conjecture, Journal of Public Economics, vol. 66, no. 1, 99-126

Mott, T. and Slattery, E. 1994. Tax incidence and macroeconomic effects in a Kaleckian model when profits finance affects investment and prices may respond to taxes, Journal of Post Keynesian Economics, vol. 16, no. 3, 391-409

Naastepad, C. W. M. and Storm, S. 2006. OECD demand regimes (1960-2000), Journal of Post Keynesian Economics, vol. 29, no. 2, 211-246

Nikiforos, M. 2016. Distribution-led growth in the long run, Review of Keynesian Economics, vol. 4, no. 4, pp. 391-408

Nikolaidi, M. 2014. Margins of safety and instability in a macrodynamic model with Minskyan insights, Structural Change and Economic Dynamics, vol. 31, 1-16

OECD 2016. National Accounts, https://stats.oecd.org/Index.aspx ?DataSetCode=NAAG, last accessed 16 November 2017

Onaran, Ö. and Galanis, G. 2014. Income distribution and growth: a global model, Environment and Planning A, vol. 46, no. 10, 2489-2513

Onaran, Ö. and Obst, T. 2016. Wage-led growth in the EU15 member-states: the effects of income distribution on growth, investment, trade balance and inflation, Cambridge Journal of Economics, vol. 40, no. 6, 1517-1551

Onaran, Ö., Boesch, V. and Leibrecht, M. 2012. How does globalization affect the implicit tax rates on labor income, capital income, and consumption in the European Union? Economic Inquiry, vol. 50, no. 4, 880-904

Onaran, Ö., Stockhammer, E. and Grafl, L. 2011. Financialisation, income distribution and aggregate demand in the USA, Cambridge Journal of Economics, vol. 35, no. 4, 637-661

Palley, T. I. 2009. Imports and the income-expenditure model: implications for fiscal policy and recession fighting, Journal of Post Keynesian Economics, vol. 32, no. 2, 311-322

Palley, T. I. 2013. Cambridge and neo-Kaleckian growth and distribution theory: comparison with an application to fiscal policy, Review of Keynesian Economics, vol. 1, no. 1, 79-104

Palley, T. I. 2014. 'Rethinking Wage vs. Profit-led Growth Theory with Implications for Policy Analysis', IMK Working Paper no. 141

Ribeiro, R.S. and Lima, G.T., 2018. Government expenditure ceiling and public debt dynamics in a demand-led micromodel, Journal of Post Keynesian Economics, 1-26

Rowthorn, R. 1981. 'Demand, Real Wages and Economic Growth', Thames Papers in Political Economy, Autumn 1-39. reprinted in Studi Economici 1982, vol. 18, 3-54

Ryoo, S. and Skott, P. 2013. Public debt and full employment in a stock-flow consistent model of a corporate economy, Journal of Post Keynesian Economics, vol. 35, no. 4, 511-528

Seguino, S. 2012. Macroeconomics, human development, and distribution, Journal of Human Development and Capabilities, vol. 13, no. 1, 59-81

Stockhammer. E. 2017. Determinants of the wage share: a panel analysis of advanced and developing economies, British Journal of Industrial Relations, vol. 55, no. 1, 3-33

Stockhammer, E., Onaran, Ö. and Ederer, S. 2009. Functional income distribution and aggregate demand in the Euro area, Cambridge Journal of Economics, vol. 33, no 1, 139159

Tavani, D. and Zamparelli, L. 2017. Government spending composition, aggregate demand, 
growth, and distribution, Review of Keynesian Economics, vol. 5, no. 2, 239-258

Taylor, L., 1985. A stagnationist model of economic growth, Cambridge Journal of Economics, 9 (4), 383-403

van Treeck, T. 2009. A synthetic, stock-flow consistent macroeconomic model of 'financialisation', Cambridge Journal of Economics, vol. 33, no. 3, 467-493

Yoshida, H. and Asada, T., 2007. Dynamic analysis of policy lag in a Keynes-Goodwin model: stability, instability, cycles and chaos, Journal of Economic Behavior and Organization, vol. $62,(3), 441-469$

You, J.I. and Dutt, A.K. 1996. Government debt, income distribution and growth, Cambridge Journal of Economics, 20 (3), 335-351

Zezza, G. and Dos Santos, C. 2004. The role of monetary policy in post Keynesian stock-flow consistent macroeconomic growth models: preliminary results, pp. 183-208 in Lavoie, M., Seccareccia, M. (eds), Central Banking in the Modern World: Alternative Perspectives, Cheltenham, UK and Northampton, MA, Edward Elgar 
Figure 1. First-round effects of an increase in the profit share

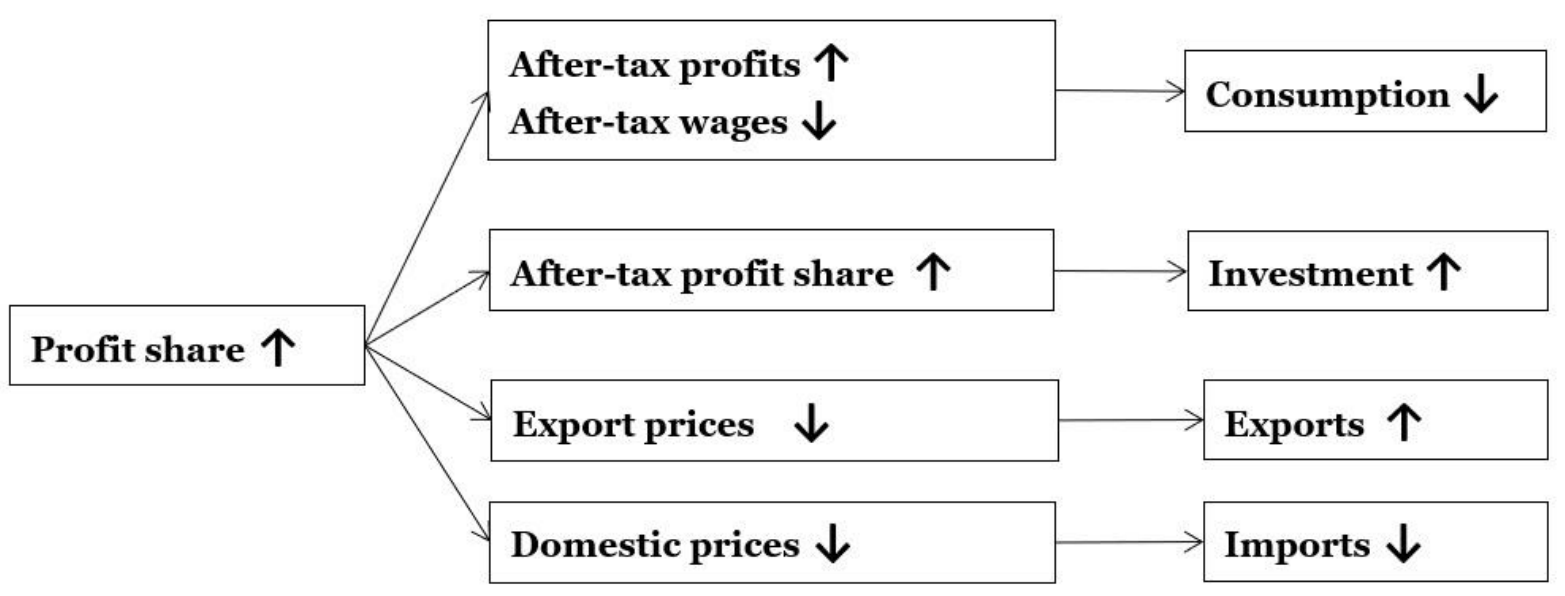

19 
Figure 2. Second-round (multiplier) effects of an increase in output caused by an exogenous shock

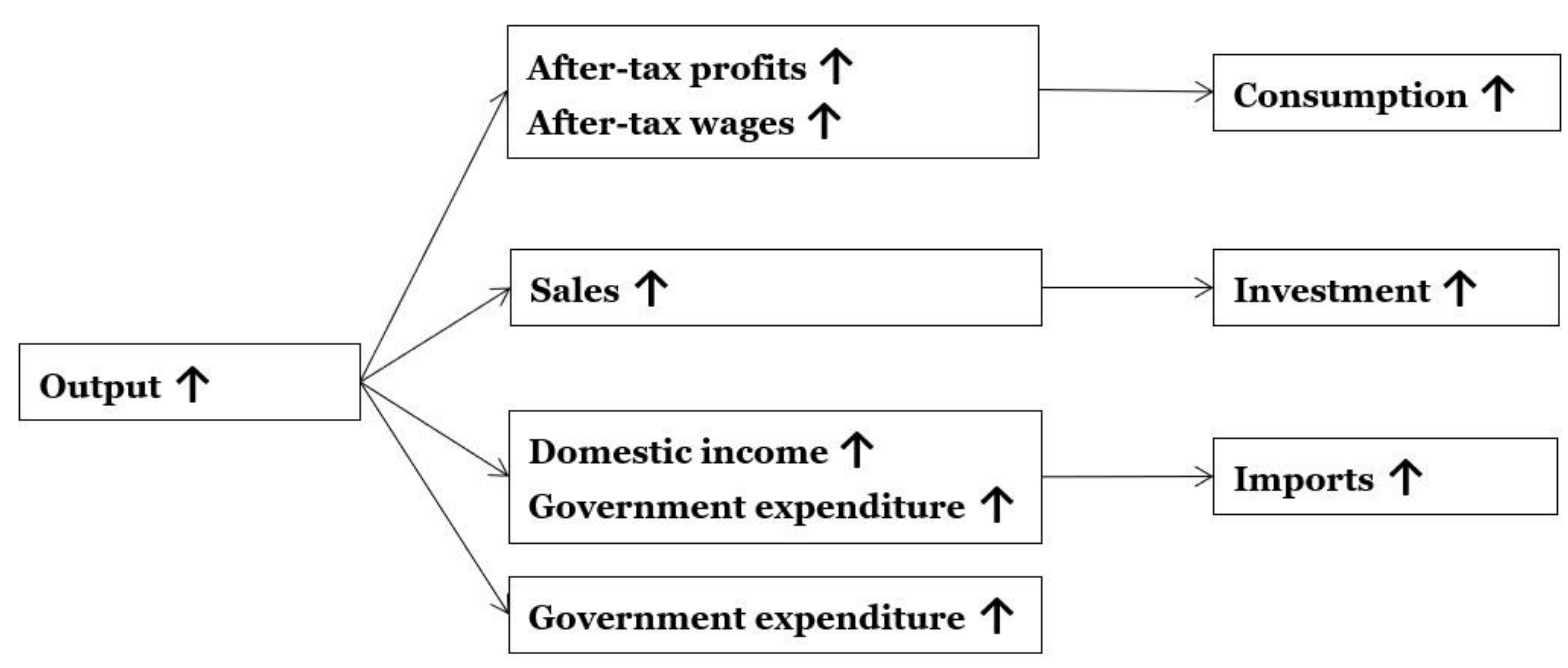


Figure 3. First-round effects of an increase in government expenditure-to-GDP ratio

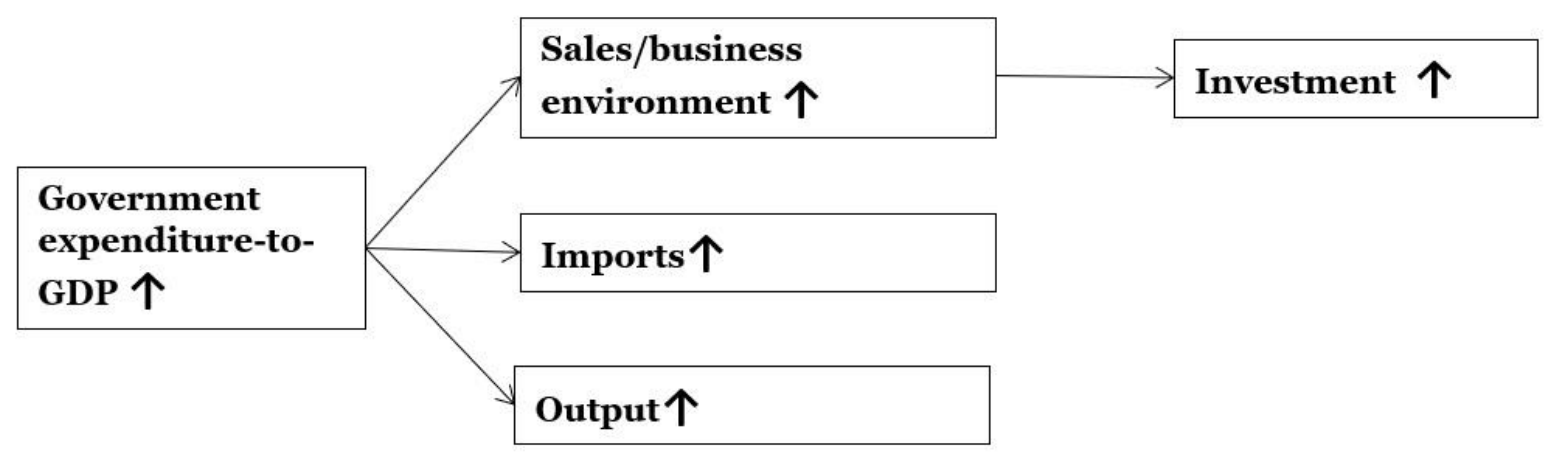


Figure 4. First-round effects of a combined increase in the tax rate on capital income and a decrease in the tax rate on labour income

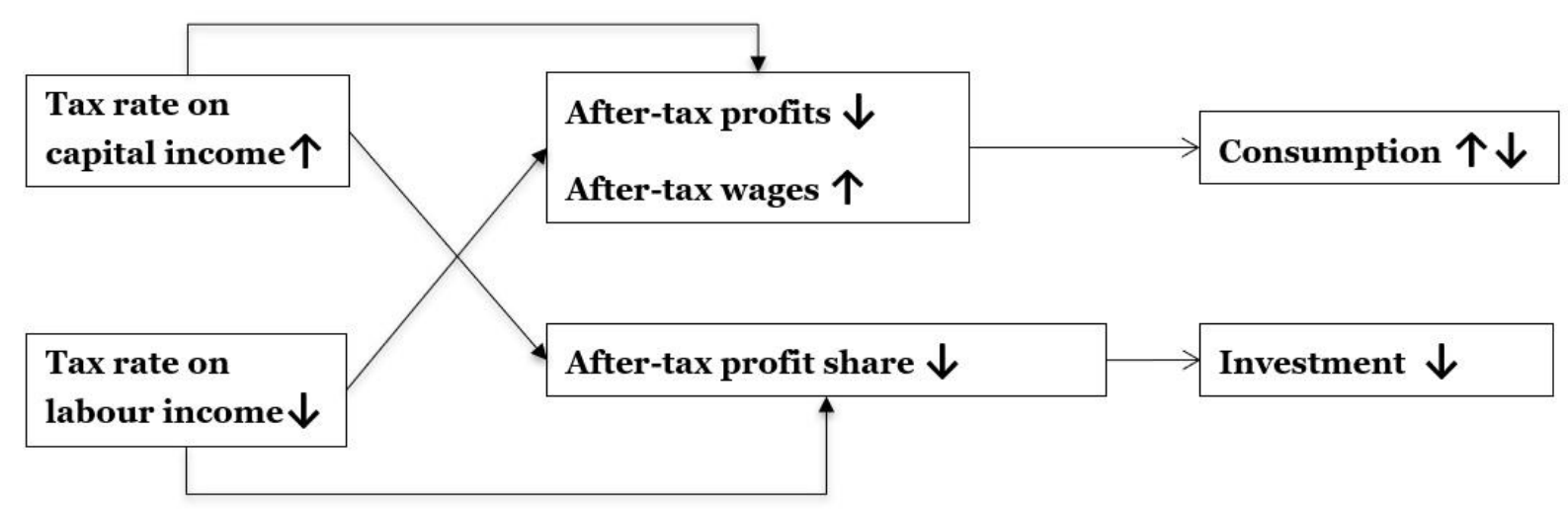


Table 1. Consumption: dependent variable dlog C (equation 1)

\begin{tabular}{|c|c|c|c|c|c|c|c|c|}
\hline & $c$ & $\operatorname{dlog}\left(1-t_{r}\right) R$ & $\operatorname{dlog}\left(1-t_{w}\right) W$ & $\operatorname{dlog}\left(C_{-1}\right)$ & $\boldsymbol{A R} 1$ & $\boldsymbol{D W}$ & $R^{2}$ & Sample \\
\hline \multirow[t]{2}{*}{$\mathbf{A}$} & 0.010 & 0.113 & 0.588 & & & 2.073 & 0.544 & $1971-2012$ \\
\hline & $(3.760) * * *$ & $(3.792) * * *$ & $(5.950) * * *$ & & & & & \\
\hline \multirow[t]{2}{*}{$\mathbf{B}$} & 0.015 & 0.094 & 0.289 & & & 1.638 & 0.339 & $1971-2012$ \\
\hline & $(5.795) * * *$ & $(2.152) * *$ & $(4.071) * * *$ & & & & & \\
\hline \multirow[t]{2}{*}{ DK } & 0.007 & 0.087 & 0.519 & & & 1.668 & 0.211 & 1971-2011 \\
\hline & (1.434) & $(1.987) * *$ & $(3.089) * * *$ & & & & & \\
\hline \multirow[t]{2}{*}{ FIN } & 0.017 & 0.106 & 0.439 & & & 1.814 & 0.553 & 1966-2012 \\
\hline & $(5.386) * * *$ & $(4.455) * * *$ & $(6.445) * * *$ & & & & & \\
\hline \multirow[t]{2}{*}{$\mathbf{F}$} & 0.014 & 0.086 & 0.515 & & & 1.608 & 0.535 & $1971-2012$ \\
\hline & $(6.307) * * *$ & $(3.100) * * *$ & $(5.802) * * *$ & & & & & \\
\hline \multirow[t]{2}{*}{$\mathbf{D}$} & 0.005 & 0.067 & 0.381 & 0.419 & & 1.810 & 0.634 & $1966-2012$ \\
\hline & (1.576) & $(1.731) *$ & $(3.711) . * * *$ & $(3.726) * * *$ & & & & \\
\hline \multirow[t]{2}{*}{ GR } & 0.018 & 0.190 & 0.399 & & 0.375 & 1.957 & 0.735 & $1972-2013$ \\
\hline & $(3.396) * * *$ & $(3.902) * * *$ & $(5.619) * * *$ & & $(2.102) * *$ & & & \\
\hline \multirow[t]{2}{*}{ IRL } & 0.011 & 0.129 & 0.457 & & & 1.989 & 0.472 & $1971-2012$ \\
\hline & $(2.036) * *$ & $(3.110) * * *$ & $(5.058) * * *$ & & & & & \\
\hline \multirow[t]{2}{*}{$\mathbf{I}$} & 0.014 & 0.112 & 0.311 & & 0.568 & 1.890 & 0.657 & $1972-2012$ \\
\hline & $(2.867) * *$ & $(4.810) * * *$ & $(3.596) * * *$ & & $(3.855) * * *$ & & & \\
\hline \multirow[t]{2}{*}{$\mathbf{L}$} & 0.016 & 0.103 & 0.350 & & & 1.741 & 0.350 & $1961-2013$ \\
\hline & $(4.087) * * *$ & $(3.451) * * *$ & $(4.920) * * *$ & & & & & \\
\hline \multirow[t]{2}{*}{ NL } & 0.000 & 0.095 & 0.338 & 0.519 & & 1.921 & 0.668 & 1971-2012 \\
\hline & $-(0.040)$ & $(3.340) * * *$ & $(3.673) * * *$ & $(4.878) * * *$ & & & & \\
\hline \multirow[t]{2}{*}{$\mathbf{P}$} & 0.018 & 0.089 & 0.574 & & & 1.821 & 0.591 & $1971-2012$ \\
\hline & $(4.495) * * *$ & $(5.287) * * *$ & $(6.867) * * *$ & & & & & \\
\hline \multirow[t]{2}{*}{$\mathbf{E}$} & 0.009 & 0.072 & 0.753 & & & 2.449 & 0.847 & $1961-2007$ \\
\hline & $(3.510) * * *$ & $(2.136) * *$ & $(15.132) * * *$ & & & & & \\
\hline \multirow[t]{2}{*}{$\mathbf{S}$} & 0.010 & 0.019 & 0.236 & 0.258 & & 1.865 & 0.282 & $1962-2012$ \\
\hline & $(2.640) * *$ & $(0.666)$ & $(2.701) * * *$ & $(1.924) *$ & & & & \\
\hline \multirow[t]{2}{*}{$\mathbf{U K}$} & 0.011 & 0.072 & 0.626 & & 0.310 & 2.038 & 0.682 & $1967-2012$ \\
\hline & $(3.268) * * *$ & $(4.288) * * *$ & $(6.761) * * *$ & & $(2.051) * *$ & & & \\
\hline
\end{tabular}

Note: t-statistics are reported in the parentheses, ***, and *** stand for $10 \%, 5 \%$, and $1 \%$ significance levels respectively. Since there are no data for tax rate on capital income in Luxemburg, the regression for this country is estimated based on the pre-tax income. $\mathrm{A}=$ Austria, $\mathrm{B}=\mathrm{Belgium}, \mathrm{DK}=\mathrm{Denmark}, \mathrm{FIN}=$ Finland, $\mathrm{F}=\mathrm{France}, \mathrm{D}=\mathrm{Germany}, \mathrm{GR}$ $=$ Greece, $\mathrm{IRL}=$ Ireland, $\mathrm{I}=$ Italy, $\mathrm{L}=$ Luxemburg, $\mathrm{NL}=$ Netherlands, $\mathrm{P}=$ Portugal, $\mathrm{E}=\mathrm{Spain}, \mathrm{S}=\mathrm{Sweden}, \mathrm{UK}=\mathrm{United}$ Kingdom 
Table 2. Private investment: dependent variable dlog I (equation 2)

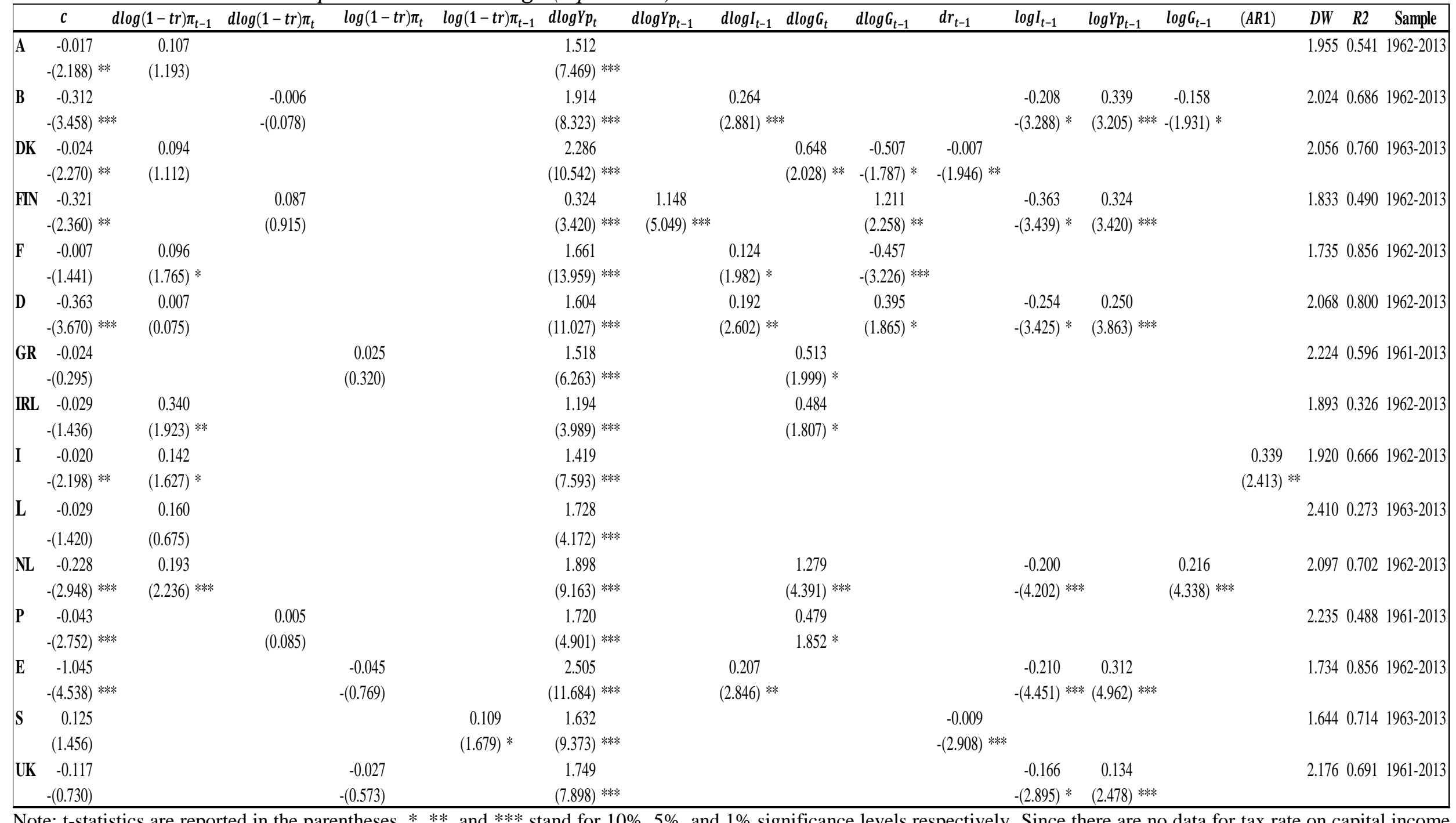

Note: t-statistics are reported in the parentheses, *,*, and $* * *$ stand for $10 \%, 5 \%$, and $1 \%$ significance levels respectively. Since there are no data for tax rate on capital income in Luxemburg, the regression for this country is estimated based on the pre-tax capital income. A = Austria, B = Belgium, DK = Denmark, FIN = Finland, F = France, D = Germany, $\mathrm{GR}=$ Greece, $\mathrm{IRL}=$ Ireland, $\mathrm{I}=$ Italy, $\mathrm{L}=$ Luxemburg, $\mathrm{NL}=$ Netherlands, $\mathrm{P}=$ Portugal, $\mathrm{E}=\mathrm{Spain}, \mathrm{S}=\mathrm{Sweden}, \mathrm{UK}=\mathrm{United}$ Kingdom 
Table 3. Price deflator: dependent variable $\operatorname{dlog} P$ (equation 8)

\begin{tabular}{|c|c|c|c|c|c|c|c|c|c|c|c|}
\hline & $c$ & $\operatorname{dlog} P_{m}$ & $\operatorname{dlog} P_{m-1}$ & $\operatorname{dlog} P_{-1}$ & $\operatorname{dlog}(u l c)$ & $\operatorname{dlog}(u l c)_{-1}$ & $\operatorname{dlog}\left(1+t_{c}\right)$ & $A R 1$ & $D W$ & $R^{2}$ & Sample \\
\hline $\mathbf{A}$ & $\begin{array}{c}0.005 \\
(2.433) * *\end{array}$ & $\begin{array}{c}0.146 \\
(3.715) * * *\end{array}$ & & $\begin{array}{c}0.453 \\
(5.320) * * *\end{array}$ & $\begin{array}{c}0.286 \\
(4.952) * * *\end{array}$ & & & & 1.920 & 0.851 & $1962-2013$ \\
\hline $\mathbf{B}$ & $\begin{array}{c}0.019 \\
(3.985) * * *\end{array}$ & $\begin{array}{c}0.158 \\
(6.721) * * *\end{array}$ & $\begin{array}{c}0.129 \\
(4.197) * * *\end{array}$ & & & $\begin{array}{c}0.214 \\
(2.456) * * *\end{array}$ & & $\begin{array}{c}0.573 \\
(3.662) * * *\end{array}$ & 2.139 & 0.813 & $1962-2013$ \\
\hline DK & $\begin{array}{c}0.008 \\
(2.423) * *\end{array}$ & $\begin{array}{c}0.183 \\
(5.266) * * *\end{array}$ & & $\begin{array}{c}0.465 \\
(4.037) * * *\end{array}$ & & $\begin{array}{c}0.249 \\
(2.698) * * *\end{array}$ & & & 2.029 & 0.865 & $1962-2013$ \\
\hline FIN & $\begin{array}{c}0.009 \\
(2.299) * *\end{array}$ & $\begin{array}{c}0.236 \\
(5.712) * * *\end{array}$ & & $\begin{array}{c}0.198 \\
(2.128) * *\end{array}$ & $\begin{array}{c}0.416 \\
(5.399) * * *\end{array}$ & & $\begin{array}{c}0.742 \\
(2.336) * *\end{array}$ & & 1.966 & 0.860 & 1966-2012 \\
\hline $\mathbf{F}$ & $\begin{array}{c}0.004 \\
(1.718) *\end{array}$ & $\begin{array}{c}0.094 \\
(3.580) * * *\end{array}$ & & $\begin{array}{c}0.633 \\
(4.635) * * *\end{array}$ & & $\begin{array}{c}0.194 \\
(1.624) *\end{array}$ & & & 1.795 & 0.907 & $1962-2013$ \\
\hline $\mathbf{D}$ & $\begin{array}{c}0.017 \\
(4.498) * * *\end{array}$ & & $\begin{array}{c}0.032 \\
(1.635) *\end{array}$ & & $\begin{array}{c}0.366 \\
(7.781) * * *\end{array}$ & & & $\begin{array}{c}0.697 \\
(8.452) * * *\end{array}$ & 2.105 & 0.841 & $1962-2013$ \\
\hline GR & $\begin{array}{c}0.019 \\
(2.870) * * *\end{array}$ & $\begin{array}{c}0.462 \\
(6.435) * * *\end{array}$ & & & $\begin{array}{l}0.4230 .000 \\
(5.932) * * *\end{array}$ & & & & 1.758 & 0.810 & $1962-2013$ \\
\hline IRL & $\begin{array}{c}0.030 \\
(2.418) * *\end{array}$ & & $\begin{array}{c}0.235 \\
(2.872) * * *\end{array}$ & & & $\begin{array}{c}0.334 \\
(2.512) * *\end{array}$ & $\begin{array}{c}1.003 \\
(2.309) * *\end{array}$ & $\begin{array}{c}0.404 \\
(2.727) * * *\end{array}$ & 2.120 & 0.753 & 1971-2012 \\
\hline I & $\begin{array}{r}0.028 \\
(1.333)\end{array}$ & $\begin{array}{c}0.084 \\
(4.292) * * *\end{array}$ & & & $\begin{array}{l}0.445 \\
8.934 * * *\end{array}$ & & $\begin{array}{c}0.909 \\
(3.251) * * *\end{array}$ & $\begin{array}{c}0.902 \\
(11.479) * * *\end{array}$ & 2.404 & 0.958 & 1971-2012 \\
\hline $\mathbf{L}$ & $\begin{array}{c}0.024 \\
(4.180) * * *\end{array}$ & $\begin{array}{c}0.523 \\
(5.076) * * *\end{array}$ & & $\begin{array}{c}-0.482 \\
-(3.605) * * *\end{array}$ & $\begin{array}{c}0.345 \\
(3.284) * * *\end{array}$ & & & & 1.651 & 0.479 & $1962-2013$ \\
\hline NL & $\begin{array}{c}0.007 \\
(2.492) * *\end{array}$ & $\begin{array}{c}0.152 \\
(4.599) * * *\end{array}$ & & $\begin{array}{c}0.448 \\
(3.656) * * *\end{array}$ & & $\begin{array}{c}0.255 \\
(2.687) * * *\end{array}$ & & & 1.997 & 0.801 & $1962-2013$ \\
\hline $\mathbf{P}$ & $\begin{array}{r}0.005 \\
(0.982)\end{array}$ & $\begin{array}{c}0.206 \\
(3.418) * * *\end{array}$ & $\begin{array}{c}0.199 \\
(3.584) * * *\end{array}$ & & & $\begin{array}{c}0.668 \\
(9.214) * * *\end{array}$ & $\begin{array}{c}0.768 \\
(1.870) *\end{array}$ & & 1.645 & 0.921 & 1981-2012 \\
\hline $\mathbf{E}$ & $\begin{array}{c}0.025 \\
(1.971) * *\end{array}$ & & $\begin{array}{c}0.078 \\
(2.700) * * *\end{array}$ & & $\begin{array}{c}0.430 \\
(5.281) * * *\end{array}$ & & $\begin{array}{c}0.640 \\
(2.335) * *\end{array}$ & $\begin{array}{l}0.857 \\
(7.580) * * *\end{array}$ & 2.257 & 0.944 & $1981-2012$ \\
\hline $\mathbf{S}$ & $\begin{array}{c}0.011 \\
(3.032) * * *\end{array}$ & $\begin{array}{c}0.156 \\
(3.915) * * *\end{array}$ & $\begin{array}{c}0.225 \\
(5.372) * * *\end{array}$ & & & $\begin{array}{c}0.407 \\
(6.697) * * *\end{array}$ & $\begin{array}{c}0.628 \\
(2.553) * *\end{array}$ & & 1.590 & 0.846 & $1971-2012$ \\
\hline UK & $\begin{array}{r}0.002 \\
(0.769)\end{array}$ & $\begin{array}{r}0.036 \\
(1.206)\end{array}$ & & $\begin{array}{c}0.380 \\
(7.491) * * *\end{array}$ & $\begin{array}{c}0.558 \\
(12.119) * * *\end{array}$ & & $\begin{array}{c}0.565 \\
(1.708) *\end{array}$ & & 2.136 & 0.945 & 1966-2012 \\
\hline
\end{tabular}

Finland, F = France, D = Germany, GR = Greece, IRL = Ireland, I = Italy, L=Luxemburg, NL = Netherlands, P = Portugal, E = Spain, S = Sweden, UK = United Kingdom 
Table 4. Export price deflator: dependent variable $\operatorname{dlog} P_{x}$ (equation 9)

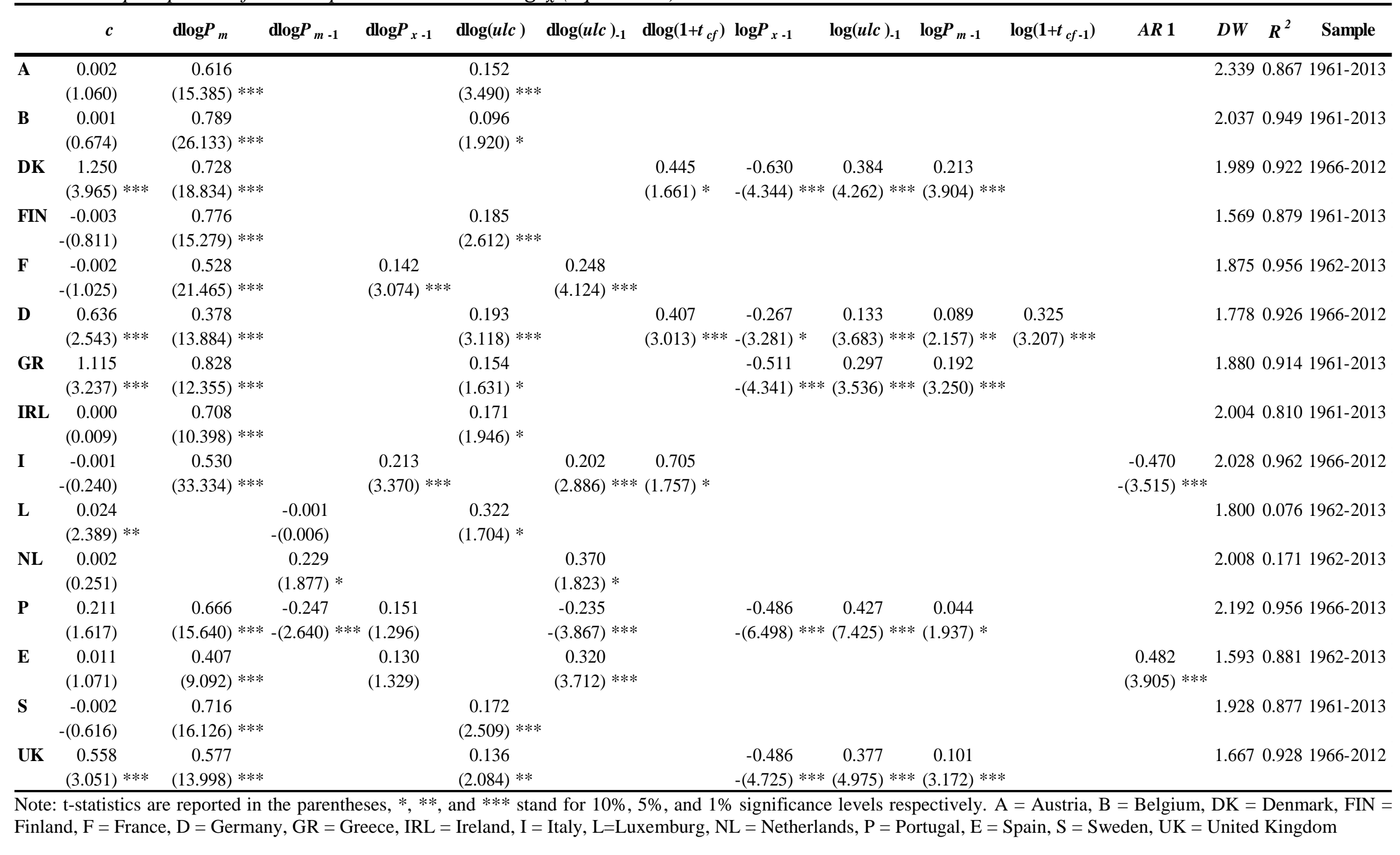


Table 5. Exports: dependent variable $\operatorname{dlog} X$ (equation 10)

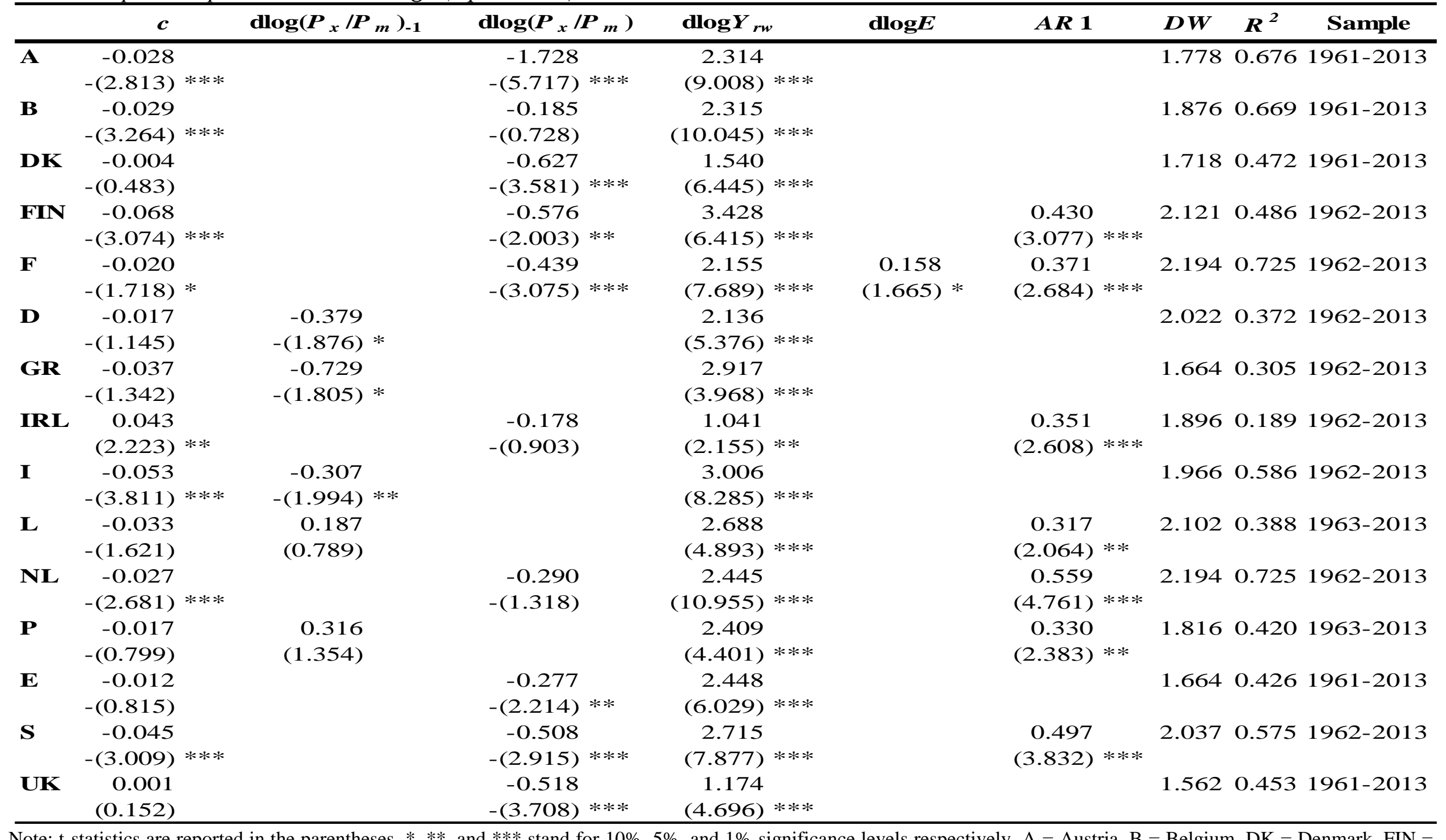

Finland, F = France, D = Germany, GR = Greece, IRL = Ireland, I = Italy, L=Luxemburg, NL = Netherlands, P = Portugal, E = Spain, S = Sweden, UK = United Kingdom 
Table 6. Imports: dependent variable $\operatorname{d} \log M($ equation 11)

\begin{tabular}{|c|c|c|c|c|c|c|c|c|c|c|c|c|c|c|c|c|c|}
\hline & $c$ & $\operatorname{dlog}\left(P / P_{m}\right)$ & ) $\operatorname{dlog}\left(P / P_{m}\right)_{-1}$ & $\operatorname{dlog} M_{-1}$ & $\operatorname{dlog} Y_{p}$ & $\operatorname{dlog} Y_{p-1}$ & $\operatorname{dlog} G$ & $\operatorname{dlog} G_{.1}$ & $\operatorname{dlog} E$ & $\log M_{-1}$ & $\log \left(P / P_{m}\right)_{-1}$ & $\log Y_{p-1}$ & $\log G_{.1}$ & $A R 1$ & $D W$ & $R^{2}$ & Sample \\
\hline A & $\begin{array}{r}-0.001 \\
-(0.091)\end{array}$ & & $\begin{array}{c}0.341 \\
(1.985)^{* *}\end{array}$ & & $\begin{array}{c}1.702 \\
(8.983) * * *\end{array}$ & & & & & & & & & & 2.256 & 50.688 & 1962-2013 \\
\hline B & $\begin{array}{r}0.003 \\
(0.436)\end{array}$ & & $\begin{array}{c}0.371 \\
(3.794) * * *\end{array}$ & $\begin{array}{c}-0.291 \\
-(2.355) \text { ** }\end{array}$ & $\begin{array}{c}1.293 \\
(7.379) * * *\end{array}$ & $\begin{array}{c}0.584 \\
*(2.373) * *\end{array}$ & & $\begin{array}{c}0.299 \\
(1.757) *\end{array}$ & & & & & & & 2.111 & 0.740 & 1962-2013 \\
\hline DK & $\begin{array}{c}0.014 \\
(2.319) * *\end{array}$ & & $\begin{array}{r}0.060 \\
(0.498)\end{array}$ & & $\begin{array}{c}1.510 \\
(8.823)\end{array}$ *** & & & & & & & & & & 2.050 & 0.637 & 1961-2013 \\
\hline FIN & $\begin{array}{r}0.003 \\
(0.474)\end{array}$ & & $\begin{array}{r}0.135 \\
(1.273)\end{array}$ & & $\begin{array}{c}1.496 \\
(12.448) * * * *\end{array}$ & & & & & & & & & & 2.342 & 0.760 & 1962-2013 \\
\hline F & $\begin{array}{c}0.014 \\
(2.486) * *\end{array}$ & & $\begin{array}{c}0.169 \\
(2.388) * *\end{array}$ & $\begin{array}{c}-0.241 \\
-(3.460))^{* * *}\end{array}$ & $\begin{array}{c}2.013 \\
(11.838)\end{array}$ *** & & & & & & & & & & 1.831 & 10.823 & 1962-2013 \\
\hline D & $\begin{array}{c}0.012 \\
(1.699) *\end{array}$ & & $\begin{array}{r}0.072 \\
(0.763)\end{array}$ & & $\begin{array}{c}1.504 \\
(9.087) \text { *** }\end{array}$ & & $\begin{array}{c}0.284 \\
(1.657) *\end{array}$ & & & & & & & & 1.548 & 0.661 & 1962-2013 \\
\hline GR & $\begin{array}{r}0.001 \\
(0.067)\end{array}$ & $\begin{array}{r}0.103 \\
(0.553)\end{array}$ & & & $\begin{array}{c}1.038 \\
(5.743) * * *\end{array}$ & $\begin{array}{c}0.442 \\
*(2.497) * *\end{array}$ & & & & & & & & & 1.752 & 0.572 & 1962-2013 \\
\hline IRL & $\begin{array}{l}-0.493 \\
-(3.176) * * *\end{array}$ & & $\begin{array}{c}0.401 \\
(3.925) * * *\end{array}$ & & $\begin{array}{c}0.632 \\
(3.503)\end{array}$ *** & $\begin{array}{c}0.479 \\
*(2.248) * *\end{array}$ & $\begin{array}{c}0.270 \\
(1.835)\end{array}$ & & $\begin{array}{c}0.320 \\
(2.570) * *\end{array}$ & $\begin{array}{c}-0.206 \\
-(3.265) \text { * }\end{array}$ & & $\begin{array}{c}0.307 \\
(3.246)\end{array}$ *** & & & 1.859 & 0.678 & 1962-2013 \\
\hline I & $\begin{array}{r}-0.006 \\
-(0.710)\end{array}$ & $\begin{array}{c}0.210 \\
(2.329) * *\end{array}$ & & & $\begin{array}{c}1.983 \\
(10.521)\end{array}$ **** & & & & & & & & & & 2.182 & 0.689 & 1961-2013 \\
\hline L & $\begin{array}{r}0.010 \\
(1.107)\end{array}$ & $\begin{array}{r}-0.025 \\
-(0.168)\end{array}$ & & & $\begin{array}{c}1.230 \\
(6.925) * * *\end{array}$ & & & & & & & & & & 2.146 & 50.490 & 1961-2013 \\
\hline NL & $\begin{array}{r}-0.155 \\
-(1.064)\end{array}$ & $\begin{array}{c}0.018 \\
(3.951)^{* * * *}\end{array}$ & $\begin{array}{c}0.139 \\
*(1.821) *\end{array}$ & & $\begin{array}{c}1.187 \\
(9.365)\end{array}$ *** & & & & & & & & & & 2.036 & 50.720 & 1962-2013 \\
\hline $\mathbf{P}$ & $\begin{array}{c}-4.574 \\
-(4.817) * * *\end{array}$ & & & & $\begin{array}{c}1.221 \\
(3.683)\end{array}$ *** & $\begin{array}{c}1.816 \\
*(6.464) * * *\end{array}$ & $\begin{array}{c}0.726 \\
(2.986) * * *\end{array}$ & & $\begin{array}{c}-0.314 \\
-(2.598)\end{array}$ **: & $\begin{array}{c}-1.051 \\
*-(7.969) * * *\end{array}$ & $\begin{array}{c}0.597 \\
(3.583) \text { *** }\end{array}$ & $\begin{array}{c}1.816 \\
*(6.464)\end{array}$ *** & & $\begin{array}{c}0.896 \\
(6.409) * * *\end{array}$ & 1.828 & 30.716 & 1961-2013 \\
\hline E & $\begin{array}{r}0.001 \\
(0.096)\end{array}$ & & $\begin{array}{c}0.244 \\
(2.271) * *\end{array}$ & & $\begin{array}{c}2.220 \\
(8.222) * * * *\end{array}$ & & & & & & & & & & 1.602 & 0.652 & 1962-2013 \\
\hline S & $\begin{array}{c}-2.760 \\
-(5.148) * * *\end{array}$ & & & & $\begin{array}{c}1.449 \\
(11.206)\end{array}$ *** & & $\begin{array}{c}0.526 \\
(1.690) *\end{array}$ & & & $\begin{array}{c}-0.481 \\
-(5.104) * * *\end{array}$ & $\begin{array}{c}0.223 \\
(4.262) * * *\end{array}$ & $\begin{array}{c}0.621 \\
*(4.521)\end{array}$ *** & $\begin{array}{c}0.202 \\
*(3.951) * * *\end{array}$ & & 1.971 & 10.763 & 1961-2013 \\
\hline UK & $\begin{array}{c}-3.542 \\
-(4.484) * * *\end{array}$ & & $\begin{array}{r}0.051 \\
(0.826)\end{array}$ & & $\begin{array}{c}1.263 \\
(10.153)\end{array}$ *** & & $\begin{array}{c}0.788 \\
(4.517) * * *\end{array}$ & & & $\begin{array}{c}-0.541 \\
-(4.633) * * *\end{array}$ & & $\begin{array}{c}0.787 \\
(4.720) * * *\end{array}$ & $\begin{array}{r}0.220 \\
*(2.806)\end{array}$ & & 2.119 & 0.782 & 1962-2013 \\
\hline
\end{tabular}

Note: t-statistics are reported in the parentheses, *,**, and *** stand for 10\%, 5\%, and $1 \%$ significance levels respectively. A = Austria, B $=$ Belgium, DK $=$ Denmark, FIN $=$ Finland, F = France, D = Germany, GR = Greece, IRL = Ireland, I = Italy, L=Luxemburg, NL = Netherlands, P = Portugal, E = Spain, S = Sweden, UK = United Kingdom 
Table 7. The effects of an isolated and a simultaneous 1\%-point fall in the profit share $(\pi)$

Policy 1: An isolated 1-\% point fall in $\pi$

\begin{tabular}{|c|c|c|c|c|}
\hline $\begin{array}{l}\text { Excess demand / } Y \\
\text { (\% points) }\end{array}$ & Multiplier & $\begin{array}{c}\text { \%-point change in } \\
\text { output }(\mathrm{d} Y / Y)\end{array}$ & $\begin{array}{l}\text { \%-point change } \\
\text { in private } \\
\text { investment } \\
(\mathrm{d} I / Y)\end{array}$ & $\begin{array}{c}\text { \%-point change in Annual } \\
\text { primary budget inflation }(\%) \\
\text { balance }(\mathrm{d} P B / Y) \quad(\operatorname{dlog} P)\end{array}$ \\
\hline
\end{tabular}

\begin{tabular}{|c|c|c|c|c|c|c|}
\hline & A & $B$ & $C=\left(A^{*} B\right)$ & $D$ & $E$ & $F$ \\
\hline A & 0.132 & 1.758 & 0.232 & 0.070 & 0.245 & 1.603 \\
\hline B & 0.109 & 0.866 & 0.094 & 0.016 & 0.175 & 0.405 \\
\hline DK & 0.243 & 2.252 & 0.548 & 0.194 & 0.252 & 1.296 \\
\hline FIN & 0.295 & 3.028 & 0.893 & 0.396 & 0.325 & 1.574 \\
\hline F & 0.279 & 2.262 & 0.630 & 0.080 & 0.239 & 1.617 \\
\hline D & 0.626 & 2.234 & 1.399 & 0.332 & 0.478 & 0.878 \\
\hline GR & 0.473 & 4.327 & 2.047 & 0.843 & 0.252 & 1.217 \\
\hline IRL & 0.031 & 1.129 & 0.035 & -0.177 & 0.211 & 0.764 \\
\hline I & 0.059 & 1.743 & 0.102 & -0.047 & 0.101 & 1.249 \\
\hline $\mathrm{L}$ & 0.153 & 0.560 & 0.086 & 0.148 & 0.342 & 0.541 \\
\hline NL & 0.170 & 4.842 & 0.822 & 0.317 & 0.308 & 1.235 \\
\hline$P$ & 0.126 & 2.096 & 0.264 & 0.104 & 0.102 & 2.877 \\
\hline $\mathrm{E}$ & 0.784 & 2.933 & 2.299 & 0.679 & 0.528 & 1.120 \\
\hline$S$ & 0.249 & 1.538 & 0.383 & 0.058 & 0.347 & 1.083 \\
\hline UK & 0.477 & 1.804 & 0.860 & 0.097 & -0.002 & 1.836 \\
\hline EU15* & & & & & & 1.286 \\
\hline
\end{tabular}

Note: A = Austria, B = Belgium, DK = Denmark, FIN = Finland, F = France, D = Germany, GR = Greece, IRL = Ireland, I = Italy, L=Luxemburg, NL = Netherlands, P = Portugal, $\mathrm{E}=$ Spain, $\mathrm{S}=$ Sweden, $\mathrm{UK}=$ United Kingdom

* Change in each country is multiplied by its share in EU15 GDP.

Policy 1: A simultaneous 1\%-point fall in $\pi$

\begin{tabular}{|c|c|c|c|}
\hline $\begin{array}{c}\text { \%-point change in } \\
\text { output }(\mathrm{d} Y / Y)\end{array}$ & $\begin{array}{l}\text { \%-point change } \\
\text { in private } \\
\text { investment } \\
(\mathrm{d} I / Y)\end{array}$ & $\begin{array}{l}\text { \%-point change in } \\
\text { primary budget } \\
\text { balance }(\mathrm{d} P B / Y)\end{array}$ & $\begin{array}{l}\text { Annual } \\
\text { inflation } \\
(\operatorname{dlog} P)\end{array}$ \\
\hline$G$ & $H$ & $I$ & $J$ \\
\hline 1.316 & 0.398 & 0.423 & 1.777 \\
\hline 0.602 & 0.100 & 0.235 & 0.700 \\
\hline 1.220 & 0.431 & 0.359 & 1.603 \\
\hline 2.112 & 0.938 & 0.445 & 1.845 \\
\hline 1.032 & 0.168 & 0.306 & 1.833 \\
\hline 1.783 & 0.423 & 0.550 & 1.166 \\
\hline 2.906 & 1.196 & 0.253 & 1.452 \\
\hline 0.372 & -0.078 & 0.216 & 0.875 \\
\hline 0.535 & 0.065 & 0.155 & 1.442 \\
\hline 0.898 & 1.552 & 0.386 & 0.773 \\
\hline 2.981 & 1.441 & 0.575 & 1.386 \\
\hline 0.754 & 0.296 & 0.163 & 3.102 \\
\hline 2.806 & 0.829 & 0.611 & 1.362 \\
\hline 1.089 & 0.262 & 0.394 & 1.335 \\
\hline 1.093 & 0.123 & 0.020 & 2.066 \\
\hline 1.411 & 0.358 & 0.330 & 1.515 \\
\hline
\end{tabular}


Table 8. The effects of an isolated and a simultaneous 1\%-point increase in government expenditure-to-GDP $\left(\kappa_{g}\right)$

Policy 2: An isolated 1\%-point increase in $\kappa_{g}$

\begin{tabular}{|c|c|c|c|c|}
\hline $\begin{array}{c}\text { Excess demand / } Y \\
\text { (\% points) }\end{array}$ & Multiplier & $\begin{array}{c}\text { \%-point change in } \\
\text { output }(\mathrm{d} Y / Y)\end{array}$ & $\begin{array}{l}\text { \%-point change } \\
\text { in private } \\
\text { investment } \\
(\mathrm{d} I / Y)\end{array}$ & $\begin{array}{l}\% \text {-point change in } \\
\text { primary budget } \\
\text { balance }(\mathrm{d} P B / Y)\end{array}$ \\
\hline
\end{tabular}

\begin{tabular}{|c|c|c|c|c|c|c|c|c|}
\hline & $\bar{A}$ & $B$ & $C=\left(A^{*} B\right)$ & $D$ & $E$ & $F$ & $G$ & $H$ \\
\hline A & 1.000 & 1.758 & 1.758 & 0.532 & -0.711 & 2.984 & 0.903 & -0.510 \\
\hline B & 0.014 & 0.866 & 0.013 & -0.582 & -0.999 & 1.043 & -0.412 & -0.876 \\
\hline FIN & 2.104 & 3.028 & 6.373 & 3.933 & -0.376 & 8.804 & 5.012 & -0.138 \\
\hline $\mathbf{F}$ & 0.622 & 2.262 & 1.407 & -0.070 & -0.766 & 2.147 & 0.092 & -0.643 \\
\hline D & 1.115 & 2.234 & 2.492 & 0.963 & -0.530 & 3.293 & 1.153 & -0.379 \\
\hline I & 1.000 & 1.743 & 1.743 & 0.453 & -0.786 & 2.554 & 0.664 & -0.686 \\
\hline $\mathbf{L}$ & 1.000 & 0.560 & 0.560 & 0.968 & -0.970 & 2.452 & 4.236 & -0.867 \\
\hline NL & 1.824 & 4.842 & 8.830 & 5.421 & 0.092 & 13.151 & 7.671 & 0.626 \\
\hline $\mathbf{P}$ & 1.133 & 2.096 & 2.374 & 1.598 & -0.702 & 3.221 & 1.930 & -0.596 \\
\hline $\mathbf{E}$ & 1.000 & 2.933 & 2.933 & 0.866 & -0.524 & 3.961 & 1.170 & -0.357 \\
\hline
\end{tabular}

Policy 2: A simultaneous 1\%-point increase in $\kappa_{g}$

$\begin{array}{ccc}\text { \%-point change in } & \begin{array}{c}\text { \%-point change } \\ \text { in private }\end{array} & \% \text {-point change in } \\ \text { output }(\mathrm{d} Y / Y) & \text { investment } & \text { primary budget } \\ & (\mathrm{d} I / Y) & \text { balance }(\mathrm{d} P B / Y)\end{array}$


Table 9. The effects of an isolated and a simultaneous 1\%-point increase in tax rate on capital income $\left(t_{r}\right)$

Policy 3: An isolated 1\%-point increase in $t_{r}$

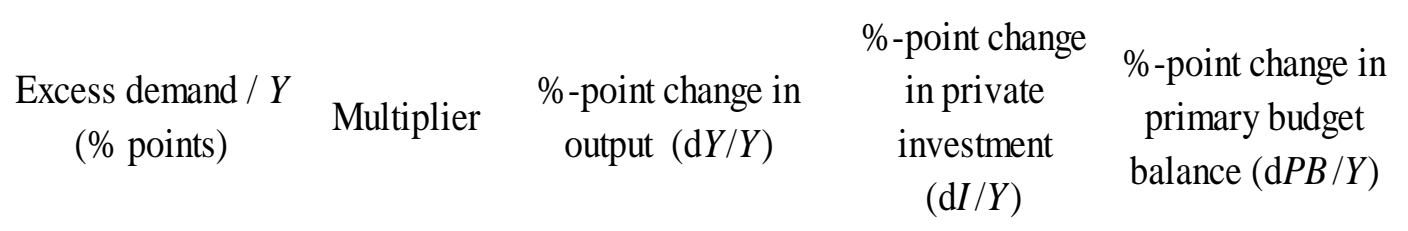

\begin{tabular}{|c|c|c|c|c|c|c|c|c|}
\hline & $A$ & $B$ & $C=\left(A^{*} B\right)$ & $D$ & $E$ & $F$ & $G$ & $H$ \\
\hline A & -0.087 & 1.758 & -0.152 & -0.046 & 0.230 & -0.268 & -0.081 & 0.211 \\
\hline B & -0.069 & 0.866 & -0.059 & -0.010 & 0.273 & -0.156 & -0.026 & 0.261 \\
\hline FIN & -0.072 & 3.028 & -0.218 & -0.097 & 0.241 & -0.453 & -0.201 & 0.218 \\
\hline F & -0.098 & 2.262 & -0.221 & -0.072 & 0.214 & -0.288 & -0.087 & 0.202 \\
\hline D & -0.090 & 2.234 & -0.200 & -0.048 & 0.258 & -0.279 & -0.066 & 0.244 \\
\hline I & -0.129 & 1.743 & -0.225 & -0.076 & 0.284 & -0.299 & -0.096 & 0.275 \\
\hline $\mathbf{L}$ & -0.042 & 0.560 & -0.023 & -0.040 & 0.401 & -0.203 & -0.350 & 0.391 \\
\hline NL & -0.167 & 4.842 & -0.808 & -0.450 & 0.153 & -1.219 & -0.664 & 0.102 \\
\hline $\mathbf{P}$ & -0.072 & 2.096 & -0.151 & -0.059 & 0.242 & -0.232 & -0.091 & 0.231 \\
\hline $\mathbf{E}$ & -0.058 & 2.933 & -0.170 & -0.050 & 0.262 & -0.270 & -0.080 & 0.246 \\
\hline
\end{tabular}

Note: A = Austria, B = Belgium, DK = Denmark, FIN = Finland, F = France, D = Germany, GR = Greece, IRL = Ireland, I = Italy, L=Luxemburg, NL = Netherlands, P = Portugal, $\mathrm{E}=$ Spain, $\mathrm{S}=$ Sweden, $\mathrm{UK}=$ United Kingdom .

* Change in each country is multiplied by its share in EU15 GDP.
Policy 3: A simultaneous 1\%-point increase in $t_{r}$

$\begin{array}{ccc}\text { \%-point change in } & \begin{array}{c}\text { \%-point change } \\ \text { in private }\end{array} & \begin{array}{c}\text { \%-point change in } \\ \text { primary budget }\end{array} \\ \text { output }(\mathrm{d} Y / Y) & \text { investment } & \text { balance }(\mathrm{d} P B / Y)\end{array}$


Table 10. The effects of an isolated and a simultaneous 1\%-point decrease in the tax rate on labour income $\left(t_{w}\right)$

Policy 4: An isolated 1\%-point decrease in $t_{w}$

\begin{tabular}{|c|c|c|c|c|}
\hline $\begin{array}{c}\text { Excess demand / } Y \\
\text { (\% points })\end{array}$ & Multiplier & $\begin{array}{c}\text { \%-point change in } \\
\text { output }(\mathrm{d} Y / Y)\end{array}$ & $\begin{array}{l}\text { \%-point change } \\
\text { in private } \\
\text { investment } \\
(\mathrm{d} I / Y)\end{array}$ & $\begin{array}{c}\% \text {-point change in } \\
\text { primary budget } \\
\text { balance }(\mathrm{d} P B / Y)\end{array}$ \\
\hline
\end{tabular}

\begin{tabular}{|c|c|c|c|c|c|c|c|c|}
\hline & $A$ & $B$ & $C=\left(A^{*} B\right)$ & $D$ & $E$ & $F$ & $G$ & $H$ \\
\hline A & 0.512 & 1.758 & 0.900 & 0.272 & 0.635 & 1.472 & 0.446 & 0.729 \\
\hline B & 0.257 & 0.866 & 0.223 & 0.037 & 0.574 & 0.702 & 0.116 & 0.631 \\
\hline FIN & 0.364 & 3.028 & 1.102 & 0.489 & 0.621 & 2.257 & 1.002 & 0.734 \\
\hline $\mathbf{F}$ & 0.450 & 2.262 & 1.017 & 0.223 & 0.673 & 1.348 & 0.295 & 0.728 \\
\hline D & 0.581 & 2.234 & 1.298 & 0.308 & 0.739 & 1.663 & 0.394 & 0.808 \\
\hline I & 0.279 & 1.743 & 0.486 & 0.126 & 0.602 & 0.877 & 0.228 & 0.650 \\
\hline $\mathbf{L}$ & 0.206 & 0.560 & 0.115 & 0.199 & 0.489 & 0.999 & 1.726 & 0.537 \\
\hline NL & 0.521 & 4.842 & 2.524 & 1.314 & 0.824 & 4.660 & 2.426 & 1.088 \\
\hline $\mathbf{P}$ & 0.461 & 2.096 & 0.965 & 0.379 & 0.679 & 1.362 & 0.535 & 0.728 \\
\hline $\mathbf{E}$ & 0.636 & 2.933 & 1.866 & 0.551 & 0.830 & 2.334 & 0.689 & 0.906 \\
\hline
\end{tabular}

Note: A = Austria, B = Belgium, DK = Denmark, FIN = Finland, F = France, D = Germany, GR = Greece, IRL = Ireland, I = Italy, L=Luxemburg, NL = Netherlands, P = Portugal, $\mathrm{E}=$ Spain, $\mathrm{S}=$ Sweden, $\mathrm{UK}=$ United Kingdom

* Change in each country is multiplied by its share in EU15 GDP.
Policy 4: A simultaneous 1\%-point decrease in $t_{w}$

$\begin{array}{ccc}\text { \%-point change in } & \begin{array}{c}\text { \%-point change } \\ \text { in private }\end{array} & \% \text {-point change in } \\ \text { output }(\mathrm{d} Y / Y) & \text { investment } & \text { primary budget } \\ & (\mathrm{d} I / Y) & \text { balance }(\mathrm{d} P B / Y)\end{array}$

$(\mathrm{d} I / Y)$

balance $(\mathrm{d} P B / Y)$ 
Table 11. The effects of an isolated and a simultaneous 1\%-point increase in tax rate on capital income ( $\left.t_{r}\right)$ and a 1\%-point decrease in the tax rate on labour income $\left(t_{w}\right)$

Policy 5: An isolated 1\%-point increase in $t_{r}$ and a $1 \%$-point fall in $t_{w}$

$\begin{array}{ccccc} & & \% \text {-point change } & \text { \%-point change in } \\ \text { Excess demand } / Y & \text { Multiplier } & \% \text {-point change in } & \text { in private } & \text { primary budget } \\ (\% \text { points }) & & \text { output }(\mathrm{d} Y / Y) & \text { investment } & \text { balance }(\mathrm{d} P B / Y)\end{array}$

Policy 5: A simultaneous 1\%-point increase in $t_{r}$ and a $1 \%$-point fall in $t_{w}$

$$
\begin{aligned}
& \% \text {-point change in output } \% \text {-point change in private } \% \text {-point change in primary } \\
& (\mathrm{d} Y / Y) \quad \text { investment }(\mathrm{d} I / Y) \quad \text { budget balance }(\mathrm{d} P B / Y)
\end{aligned}
$$

\begin{tabular}{|c|c|c|c|c|c|c|c|c|}
\hline & $A$ & $B$ & $C=\left(A^{*} B\right)$ & $D$ & $E$ & $F$ & $G$ & $H$ \\
\hline A & 0.426 & 1.758 & 0.748 & 0.226 & 0.865 & 1.204 & 0.364 & 0.940 \\
\hline B & 0.189 & 0.866 & 0.163 & 0.027 & 0.847 & 0.545 & 0.090 & 0.893 \\
\hline DK & 0.342 & 2.252 & 0.771 & 0.272 & 0.844 & 1.179 & 0.417 & 0.909 \\
\hline FIN & 0.292 & 3.028 & 0.883 & 0.392 & 0.862 & 1.804 & 0.801 & 0.952 \\
\hline $\mathbf{F}$ & 0.352 & 2.262 & 0.796 & 0.150 & 0.886 & 1.060 & 0.208 & 0.930 \\
\hline D & 0.491 & 2.234 & 1.098 & 0.260 & 0.998 & 1.384 & 0.328 & 1.052 \\
\hline GR & 0.206 & 4.327 & 0.891 & 0.367 & 0.843 & 1.500 & 0.617 & 0.844 \\
\hline IRL & 0.195 & 1.129 & 0.220 & 0.031 & 0.794 & 0.430 & 0.093 & 0.798 \\
\hline I & 0.150 & 1.743 & 0.261 & 0.050 & 0.886 & 0.578 & 0.133 & 0.925 \\
\hline L & 0.164 & 0.560 & 0.092 & 0.159 & 0.890 & 0.796 & 1.376 & 0.928 \\
\hline NL & 0.354 & 4.842 & 1.716 & 0.864 & 0.977 & 3.440 & 1.762 & 1.190 \\
\hline $\mathbf{P}$ & 0.389 & 2.096 & 0.814 & 0.320 & 0.920 & 1.130 & 0.444 & 0.960 \\
\hline $\mathbf{E}$ & 0.579 & 2.933 & 1.697 & 0.501 & 1.091 & 2.064 & 0.610 & 1.151 \\
\hline S & 0.236 & 1.538 & 0.364 & 0.085 & 0.757 & 0.803 & 0.212 & 0.786 \\
\hline UK & 0.416 & 1.804 & 0.750 & 0.085 & 0.858 & 0.895 & 0.101 & 0.872 \\
\hline EU15* & & & & & & 1.223 & 0.336 & 0.969 \\
\hline
\end{tabular}

Denmark,

* Change in each country is multiplied by its share in EU15 GDP. 
Appendix A. Effects of isolated changes in profit share and fiscal policy on aggregate demand, private investment and primary budget balance

\section{A.1 Effects of changes in profit share}

The total effect of a change in profit share $(\pi)$ in equilibrium aggregate demand (AD) is given by:

$$
\frac{d Y}{d \pi}=\frac{d C}{d \pi}+\frac{d I}{d \pi}+\frac{d N X}{d \pi}+\frac{d G}{d \pi}
$$

Dividing through by $Y$, yields:

$$
\frac{d Y / Y}{d \pi}=\frac{d C / Y}{d \pi}+\frac{d I / Y}{d \pi}+\frac{d N X / Y}{d \pi}+\frac{d G / Y}{d \pi}
$$

and

$$
\begin{aligned}
& \frac{d C / Y}{d \pi}=\frac{\partial C / Y}{\partial \pi}+\frac{\partial C}{\partial Y} \frac{\partial Y / Y}{\partial \pi} \\
& \frac{d I / Y}{d \pi}=\frac{\partial I / Y}{\partial \pi}+\frac{\partial I}{\partial Y} \frac{\partial Y / Y}{\partial \pi} \\
& \frac{d N X / Y}{d \pi}=\frac{\partial N X / Y}{\partial \pi}+\frac{\partial N X}{\partial Y} \frac{\partial Y / Y}{\partial \pi} \\
& \frac{d G / Y}{d \pi}=\frac{\partial G}{\partial Y} \frac{\partial Y / Y}{\partial \pi}
\end{aligned}
$$

Substituting equations (A3), (A4), (A5) and (A6) into (A2) and solving for $\frac{\partial Y / Y}{\partial \pi}$, we obtain:

$$
\frac{\partial Y / Y}{\partial \pi}=\frac{\frac{\partial C / Y}{\partial \pi}+\frac{\partial I / Y}{\partial \pi}+\frac{\partial N X / Y}{\partial \pi}}{1-\frac{\partial C}{\partial Y}-\frac{\partial I}{\partial Y}-\frac{\partial N X}{\partial Y}-\frac{\partial G}{\partial Y}}
$$

In Equation (A7) the term $1-\frac{\partial C}{\partial Y}-\frac{\partial I}{\partial Y}-\frac{\partial N X}{\partial Y}-\frac{\partial G}{\partial Y}$ captures the multiplier effect and has to be positive for stability. The effect of an isolated $1 \%$-point increase in $\pi$ on percentage (\%) change in $\mathrm{AD}$ is equal to the multiplier times the effect on excess demand $\left(\frac{\partial C / Y}{\partial \pi}+\frac{\partial I / Y}{\partial \pi}+\frac{\partial N X / Y}{\partial \pi}\right.$ ) .

The marginal effect of $\pi$ on consumption/GDP is given by:

$$
\frac{\partial C / Y}{\partial \pi}=\frac{\partial C / Y}{\partial R^{\prime}} \frac{\partial R^{\prime}}{\partial \pi}+\frac{\partial C / Y}{\partial W^{\prime}} \frac{\partial W^{\prime}}{\partial \pi}=c_{r} \frac{C / Y}{\left(1-t_{r}\right) R}\left(1-t_{r}\right) Y-c_{w} \frac{C / Y}{\left(1-t_{w}\right) W}\left(1-t_{w}\right) Y=c_{r} \frac{C}{R}-c_{w} \frac{C}{W}
$$

The marginal effect of the profit share on private investment/GDP is given by:

$$
\frac{\partial I / Y}{\partial \pi}=\frac{\partial I / Y}{\partial \pi^{\prime}} \frac{\partial \pi^{\prime}}{\partial \pi}=\frac{\partial I / Y}{\partial\left(1-t_{r}\right) \pi} \frac{\partial\left(1-t_{r}\right) \pi}{\partial \pi}=i_{\pi} \frac{I / Y}{\left(1-t_{r}\right) \pi}\left(1-t_{r}\right)=i_{\pi} \frac{I / Y}{\pi}
$$


The marginal effect of $\pi$ on net exports/GDP is given by:

$\frac{\partial N X / Y}{\partial \pi}=\frac{\partial X / Y}{\partial \pi}-\frac{\partial M / Y}{\partial \pi}$

where:

$\frac{\partial X / Y}{\partial \pi}=\left(\frac{\partial \log X}{\partial \log P_{x}} \frac{\partial \log P_{x}}{\partial \log (\text { ulc })} \frac{\partial \log (\text { ulc })}{\partial \log (\text { rulc })} \frac{\partial \log (\text { rulc })}{\partial \log \pi}\right) \frac{X / Y}{\pi}=-\left(\right.$ eXPxePxulc $\left.\frac{1}{1-e_{\text {Pulc }}} \frac{Y_{f}}{Y}\right) \frac{X / Y}{\text { rulc }}$
$\frac{\partial M / Y}{\partial \pi}=\left(\frac{\partial \log M}{\partial \log P} \frac{\partial \log P}{\partial \log (\text { ulc })} \frac{\partial \log (\text { ulc })}{\partial \log (\text { rulc })} \frac{\partial \log (\text { rulc })}{\partial \log \pi}\right) \frac{M / Y}{\pi}=-\left(\right.$ eMPePulc $\left.\frac{1}{1-e_{P u l c}} \frac{Y_{f}}{Y}\right) \frac{M / Y}{\text { rulc }}$

The marginal effect of output on consumption is given by:

$\frac{\partial C}{\partial Y}=\frac{\partial C}{\partial R^{\prime}} \frac{\partial R^{\prime}}{\partial Y}+\frac{\partial C}{\partial W^{\prime}} \frac{\partial W^{\prime}}{\partial Y}=c_{r} \frac{C}{\left(1-t_{r}\right) R}\left(1-t_{r}\right) \pi+c_{w} \frac{C}{\left(1-t_{w}\right) W}\left(1-t_{w}\right)(1-\pi)=\left(c_{r}+c_{w}\right) \frac{C}{Y}$

The marginal effect of output on private investment is given by:

$\frac{\partial I}{\partial Y}=\frac{\partial I}{\partial Y_{p}} \frac{\partial Y_{p}}{\partial Y}+\frac{\partial I}{\partial G} \frac{\partial G}{\partial Y}=i_{y} \frac{I}{Y_{p}}\left(1-\kappa_{g}\right)+i_{g} \frac{I}{G} \kappa_{g}=\left(i_{y}+i_{g}\right) \frac{I}{Y}$

The marginal effect of output on net exports is given by:

$\frac{\partial N X}{\partial Y}=-\frac{\partial M}{\partial Y}=-\left(\frac{\partial M}{\partial Y_{p}} \frac{\partial Y_{p}}{\partial Y}+\frac{\partial M}{\partial G} \frac{\partial G}{\partial Y}\right)=-\left(m_{y} \frac{M}{Y_{p}}\left(1-\kappa_{g}\right)+m_{g} \frac{M}{G} \kappa_{g}\right)=-\left(m_{y}+m_{g}\right) \frac{M}{Y}$

The marginal effect of output on government expenditure is given by:

$\frac{\partial G}{\partial Y}=\frac{\partial \kappa_{g} Y}{\partial Y}=\kappa_{g}$

We calculate the total effects of $\pi$ on primary budget balance/GDP as follows:

$\frac{d P B / Y}{d \pi}=\frac{d\left(T-G_{t o t}\right) / Y}{d \pi}=\frac{\partial T / Y}{\partial \pi}+\frac{\partial T}{\partial Y} \frac{\partial Y / Y}{\partial \pi}-\frac{\partial G}{\partial Y} \frac{\partial Y / Y}{\partial \pi}$

The marginal effect of $\pi$ on taxes/GDP is given by:

$\frac{\partial T / Y}{\partial \pi}=\frac{\partial\left(t_{w} W+t_{r} R+t_{c} C\right) / Y}{\partial \pi}=t_{w} \frac{\partial W / Y}{\partial \pi}+t_{r} \frac{\partial R / Y}{\partial \pi}+t_{c} \frac{\partial C / Y}{\partial \pi}=-t_{w}+t_{r}+t_{c}\left(c_{r} \frac{C}{R}-c_{w} \frac{C}{W}\right)$

The marginal effect of output on taxes is given by:

$\frac{\partial T}{\partial Y}=\frac{\partial\left(t_{w} W+t_{r} R+t_{c} C\right)}{\partial Y}=t_{w} \frac{\partial W}{\partial Y}+t_{r} \frac{\partial R}{\partial Y}+t_{c} \frac{\partial C}{\partial Y}=t_{w}(1-\pi)+t_{r} \pi+t_{c}\left(c_{r}+c_{w}\right) \frac{C}{Y}$ 


\section{A.2 Effects of changes in government expenditure-to-GDP ratio}

The total effect of a change in government expenditure/GDP $\left(\kappa_{g}\right)$ on equilibrium AD is as follows:

$\frac{d Y}{d \kappa_{g}}=\frac{d C}{d \kappa_{g}}+\frac{d I}{d \kappa_{g}}+\frac{d N X}{d \kappa_{g}}+\frac{d G}{d \kappa_{g}}$

Dividing through by $Y$ :

$\frac{d Y / Y}{d \kappa_{g}}=\frac{d C / Y}{d \kappa_{g}}+\frac{d I / Y}{d \kappa_{g}}+\frac{d N X / Y}{d \kappa_{g}}+\frac{d G / Y}{d \kappa_{g}}$

We know that:

$$
\begin{aligned}
& \frac{d C / Y}{d \kappa_{g}}=\frac{\partial C}{\partial Y} \frac{\partial Y / Y}{\partial \kappa_{g}} \\
& \frac{d I / Y}{d \kappa_{g}}=\frac{\partial I / Y}{\partial \kappa_{g}}+\frac{\partial I}{\partial Y} \frac{\partial Y / Y}{\partial \kappa_{g}} \\
& \frac{d N X / Y}{d \kappa_{g}}=\frac{\partial N X / Y}{\partial \kappa_{g}}+\frac{\partial N X}{\partial Y} \frac{\partial Y / Y}{\partial \kappa_{g}} \\
& \frac{d G / Y}{d \kappa_{g}}=\frac{\partial G / Y}{\partial \kappa_{g}}+\frac{\partial G}{\partial Y} \frac{\partial Y / Y}{\partial \kappa_{g}}
\end{aligned}
$$

Substituting equations (A20), (A21), (A22) and (A23) into (A19) and solving for $\frac{\partial Y / Y}{\partial \kappa g}$, we obtain:

$$
\frac{\partial Y / Y}{\partial \kappa_{g}}=\frac{\frac{\partial I / Y}{\partial \kappa_{g}}+\frac{\partial N X / Y}{\partial \kappa_{g}}+\frac{\partial G / Y}{\partial \kappa_{g}}}{1-\frac{\partial C}{\partial Y}-\frac{\partial I}{\partial Y}-\frac{\partial N X}{\partial Y}-\frac{\partial G}{\partial Y}}
$$

The effect of an isolated 1\%-point increase in $\kappa_{g}$ on percentage (\%) change in AD is equal to the multiplier times the effect on excess demand $\left(\frac{\partial I / Y}{\partial \kappa_{g}}+\frac{\partial N X / Y}{\partial \kappa_{g}}+\frac{\partial G / Y}{\partial \kappa_{g}}\right)$.

The marginal effect of $\kappa_{g}$ on investment/GDP is given by:

$$
\frac{\partial I / Y}{\partial \kappa_{g}}=\frac{\partial I / Y}{\partial G} \frac{\partial G}{\partial \kappa_{g}}=i_{g} \frac{I / Y}{G} Y=i_{g} \frac{I}{G}
$$

The marginal effect of $\kappa_{g}$ on net exports/GDP is given by:

$$
\frac{\partial N X / Y}{\partial \kappa_{g}}=-\frac{\partial M}{\partial \kappa_{g}}=-m_{g} \frac{M}{G}
$$

The marginal effect of $\kappa_{g}$ on government expenditure/GDP is given by: 
$\frac{\partial G / Y}{\partial \kappa_{g}}=\frac{\partial\left(\kappa_{g} Y\right) / Y}{\partial \kappa_{g}}=\frac{Y}{Y}=1$

We calculate the total effects of $\kappa_{g}$ on primary budget balance/GDP as follows:

$\frac{d P B / Y}{d \kappa_{g}}=\frac{d\left(T-G_{t o t}\right) / Y}{d \kappa_{g}}=\frac{\partial T}{\partial Y} \frac{\partial Y / Y}{\partial \kappa_{g}}-\frac{\partial G / Y}{\partial \kappa_{g}}-\frac{\partial G}{\partial Y} \frac{\partial Y / Y}{\partial \kappa_{g}}$

\section{A.3 Effects of changes in the tax rate on capital income}

The total effect of a change in the tax rate on capital income $\left(t_{r}\right)$ on equilibrium AD is as follows:

$\frac{d Y}{d t_{r}}=\frac{d C}{d t_{r}}+\frac{d I}{d t_{r}}+\frac{d N X}{d t_{r}}+\frac{d G}{d t_{r}}$

Dividing through by $Y$ :

$\frac{d Y / Y}{d t_{r}}=\frac{d C / Y}{d t_{r}}+\frac{d I / Y}{d t_{r}}+\frac{d N X / Y}{d t_{r}}+\frac{d G / Y}{d t_{r}}$

We know that:

$\frac{d C / Y}{d t_{r}}=\frac{\partial C / Y}{\partial t_{r}}+\frac{\partial C}{\partial Y} \frac{\partial Y / Y}{\partial t_{r}}$

$\frac{d I / Y}{d t_{r}}=\frac{\partial I / Y}{\partial t_{r}}+\frac{\partial I}{\partial Y} \frac{\partial Y / Y}{\partial t_{r}}$

$\frac{d N X / Y}{d t_{r}}=\frac{\partial N X}{\partial Y} \frac{\partial Y / Y}{\partial t_{r}}$

$\frac{d G / Y}{d t_{r}}=\frac{\partial G}{\partial Y} \frac{\partial Y / Y}{\partial t_{r}}$

Substituting equations (A31), (A32), (A33) and (A34) into (A30) and solving for $\frac{\partial Y / Y}{\partial t_{r}}$, we obtain:

$\frac{\partial Y / Y}{d t_{r}}=\frac{\frac{\partial C / Y}{\partial t_{r}}+\frac{\partial I / Y}{\partial t_{r}}}{1-\frac{\partial C}{\partial Y}-\frac{\partial I}{\partial Y}-\frac{\partial N X}{\partial Y}-\frac{\partial G}{\partial Y}}$

The effect of an isolated 1\%-point increase in $t_{r}$ on percentage (\%) change in AD is equal to the multiplier times the effect on excess demand $\left(\frac{\partial C / Y}{\partial t_{r}}+\frac{\partial I / Y}{\partial t_{r}}\right)$.

The marginal effect of $t_{r}$ on consumption/GDP is given by: 
$\frac{\partial C / Y}{\partial t_{r}}=\frac{\partial C / Y}{\partial R^{\prime}} \frac{\partial R^{\prime}}{\partial t_{r}}=c_{r} \frac{C / Y}{\left(1-t_{r}\right) R}(-R)=-c_{r} \frac{C / Y}{1-t_{r}}$

The marginal effect of $t_{r}$ on investment/GDP is given by:

$\frac{\partial I / Y}{\partial t_{r}}=\frac{\partial I / Y}{\partial \pi^{\prime}} \frac{\partial \pi^{\prime}}{\partial t_{r}}=i_{\pi} \frac{I / Y}{\left(1-t_{r}\right) \pi} \frac{\partial\left(1-t_{r}\right) \pi}{\partial t_{r}}=i_{\pi} \frac{I / Y}{\left(1-t_{r}\right) \pi}(-\pi)=-i_{\pi} \frac{I / Y}{\left(1-t_{r}\right)}$

We calculate the total effects of $t_{r}$ on primary budget balance/Y as follows:

$\frac{d P B / Y}{d t_{r}}=\frac{d\left(T-G_{t o t}\right) / Y}{d t_{r}}=\frac{\partial T / Y}{\partial t_{r}}+\frac{\partial T}{\partial Y} \frac{\partial Y / Y}{\partial t_{r}}-\frac{\partial G}{\partial Y} \frac{\partial Y / Y}{\partial t_{r}}$

The marginal effect of $t_{r}$ on taxes/GDP is given by:

$\frac{\partial T / Y}{\partial t_{r}}=\frac{\partial\left(t_{w} W+t_{r} R+t_{c} C\right) / Y}{\partial t_{r}}=\frac{R}{Y}+t_{c} \frac{\partial C / Y}{\partial t_{r}}$

\section{A.4 Effects of changes in the tax rate on labour income}

The total effects of a change in the tax rate on labour income $\left(t_{w}\right)$ on equilibrium AD are:

$\frac{d Y}{d t_{w}}=\frac{d C}{d t_{w}}+\frac{d I}{d t_{w}}+\frac{d N X}{d t_{w}}+\frac{d G}{d t_{w}}$

Dividing through by $Y$ :

$\frac{d Y / Y}{d t_{w}}=\frac{d C / Y}{d t_{w}}+\frac{d I / Y}{d t_{w}}+\frac{d N X / Y}{d t_{w}}+\frac{d G / Y}{d t_{w}}$

We know that:

$$
\begin{aligned}
& \frac{d C / Y}{d t_{w}}=\frac{\partial C / Y}{\partial t_{w}}+\frac{\partial C}{\partial Y} \frac{\partial Y / Y}{\partial t_{w}} \\
& \frac{d I / Y}{d t_{w}}=\frac{\partial I / Y}{\partial t_{w}}+\frac{\partial I}{\partial Y} \frac{\partial Y / Y}{\partial t_{w}} \\
& \frac{d N X / Y}{d t_{w}}=\frac{\partial N X}{\partial Y} \frac{\partial Y / Y}{\partial t_{w}} \\
& \frac{d G / Y}{d t_{w}}=\frac{\partial G}{\partial Y} \frac{\partial Y / Y}{\partial t_{w}}
\end{aligned}
$$

Substituting equations (A42), (A43), (A44) and (A45) into (A41) and solving for $\frac{\partial Y / Y}{\partial t_{w}}$, we obtain:

$$
\frac{\partial Y / Y}{\partial t_{w}}=\frac{\frac{\partial C / Y}{\partial t_{w}}}{1-\frac{\partial C}{\partial Y}-\frac{\partial I}{\partial Y}-\frac{\partial N X}{\partial Y}-\frac{\partial G}{\partial Y}}
$$


The effect of an isolated 1\%-point increase in $t_{w}$ on percentage (\%) change in AD is equal to the multiplier times the effect on excess demand $\left(\frac{\partial C / Y}{\partial t_{w}}\right)$.

The marginal effect of $t_{w}$ on consumption/GDP is given by:

$\frac{\partial C / Y}{\partial t_{w}}=\frac{\partial C / Y}{\partial W^{\prime}} \frac{\partial W^{\prime}}{\partial t_{w}}=c_{w} \frac{C / Y}{\left(1-t_{w}\right) W}(-W)=-c_{w} \frac{C / Y}{\left(1-t_{w}\right)}$

We calculate the total effects of $t_{w}$ on primary budget balance/GDP as follows:

$\frac{d P B / Y}{d t_{w}}=\frac{d\left(T-G_{\text {tot }}\right) / Y}{d t_{w}}=\frac{\partial T / Y}{\partial t_{w}}+\frac{\partial T}{\partial Y} \frac{\partial Y / Y}{\partial t_{w}}-\frac{\partial G}{\partial Y} \frac{\partial Y / Y}{\partial t_{w}}$

The marginal effect of $t_{w}$ on taxes/GDP is given by:

$\frac{\partial T / Y}{\partial t_{w}}=\frac{\partial\left(t_{w} W+t_{r} R+t_{c} C\right) / Y}{\partial t_{w}}=\frac{W}{Y}+t_{c} \frac{\partial C / Y}{\partial t_{w}}$ 
Appendix B. Effects of simultaneous changes in profit share and fiscal policy on aggregate demand, private investment and primary budget balance

\section{B.1 Policy 1: Effects of changes in profit share}

We model a 1\%-point increase in profit share on the percentage (\%) change in GDP of each country as follows.

$\left[\frac{\partial Y}{Y}\right]_{15 x 1}=E_{15 \times 15}[\partial \pi]_{15 x 1}+H_{15 x 15}^{\prime}\left[\frac{\partial Y}{Y}\right]_{15 x 1}+P_{15 x 15}[\partial \pi]_{15 x 1}+W_{15 x 15}\left[\frac{\partial Y}{Y}\right]_{15 x 1}$

$E_{15 \times 15}$ is a matrix, whose diagonal elements are the effect of a change in $\pi$ in country $j$ on excess demand in country $j$ :

$E_{15 \times 15}=\left[\begin{array}{ccc}\frac{\partial C_{1} / Y_{1}}{\partial \pi_{1}}+\frac{\partial I_{1} / Y_{1}}{\partial \pi_{1}}+\frac{\partial N X_{1} / Y_{1}}{\partial \pi_{1}} & 0 & . \\ 0 & \cdot & 0 \\ \cdot & \cdot & \cdot \\ 0 & 0 & \cdot \frac{\partial C_{15} / Y_{1}}{\partial \pi_{15}}+\frac{\partial I_{15} / Y_{15}}{\partial \pi_{15}}+\frac{\partial N X_{15} / Y_{15}}{\partial \pi_{15}}\end{array}\right]$

where $\frac{\partial C_{i} / Y_{i}}{\partial \pi_{i}}$ is defined in equation (A8), $\frac{\partial I_{i} / Y_{i}}{\partial \pi_{i}}$ is defined in equation (A9) and $\frac{\partial N X_{i} / Y_{i}}{\partial \pi_{i}}$ is defined in equation (A10).

Matrix $H^{\prime} 15 \times 15$ reflects the national multiplier effects and hence shows the effect of an autonomous change in excess demand:

$$
H_{15 \times 15}^{\prime}=\left[\begin{array}{cccc}
\frac{\partial C_{1}}{\partial Y_{1}}+\frac{\partial I_{1}}{\partial Y_{1}}+\frac{\partial N X_{1}}{\partial Y_{1}}+\frac{\partial G_{1}}{\partial Y_{1}} & 0 & . & 0 \\
0 & \cdot & \cdot \\
\cdot & \cdot & \cdot \\
0 & 0 & \frac{\partial C_{15}}{\partial Y_{15}}+\frac{\partial I_{15}}{\partial Y_{15}}+\frac{\partial N X_{15}}{\partial Y_{15}}+\frac{\partial G_{15}}{\partial Y_{15}}
\end{array}\right]
$$

where $\frac{\partial C_{i}}{\partial Y_{i}}$ is defined in equation (A11), $\frac{\partial I_{i}}{\partial Y_{i}}$ is defined in equation (A12), $\frac{\partial N X_{i}}{\partial Y_{i}}$ is defined in equation (A13) and $\frac{\partial G_{i}}{\partial Y_{i}}$ is defined in equation (A14).

Matrix $P_{15 \times 15}$ illustrates the effect of a change in trade partners' $\pi$ on import prices and hence on net exports in each country.

$$
P_{15 \times 15}=\left[\begin{array}{ccc}
0 & \frac{\partial N X_{1} / Y_{1}}{\partial \pi_{2}} \frac{M_{21}}{M_{1}} & \frac{\partial N X_{1} / Y_{1}}{\partial \pi_{15}} \frac{M_{151}}{M_{1}} \\
\frac{\partial N X_{2} / Y_{2}}{\partial \pi_{1}} \frac{M_{12}}{M_{2}} & \cdot & . \\
\frac{\partial N X_{15} / \dot{Y}_{15}}{\partial \pi_{1}} \frac{M_{115}}{M_{15}} \frac{\partial N X_{15} / \dot{Y}_{15}}{\partial \pi_{2}} \frac{M_{215}}{M_{15}} . & 0
\end{array}\right]
$$


where $\frac{\partial N X_{i} / Y_{i}}{\partial \pi_{i}}$ is defined in equation (A10).

Finally, matrix $W_{15 \times 15}$ shows effects of a change in trade partners' GDP on exports of each country.

$W_{15 \times 15}=\left[\begin{array}{ccc}0 & e_{X Y r w, 1} \frac{X_{1}}{Y_{1}} \frac{Y_{2}}{Y_{w}} \cdot e_{X Y r w, 1} \frac{X_{1}}{Y_{1}} \frac{Y_{15}}{Y_{w}} \\ e_{X Y r w, 2} \frac{X_{2}}{Y_{2}} \frac{Y_{1}}{Y_{w}} & \cdot & . e_{X Y r w, 2} \frac{X_{2}}{Y_{2}} \frac{Y_{15}}{Y_{w}} \\ e_{X Y r w, 15} \frac{X_{15}}{Y_{15}} \frac{Y_{1}}{Y_{w}} e_{X Y r w, 15} \frac{X_{15}}{Y_{15}} \frac{Y_{2}}{Y_{w}} & \cdot & 0\end{array}\right]$

where $e_{X Y r w, i}=\frac{\partial \log X_{i}}{\partial \log Y_{r w, i}}=x_{Y r w}$ and $Y_{w}$ denotes world GDP.

Solving equation (B1) for $\left[\frac{\partial Y}{Y}\right]_{15 \times 1}$ gives us the equivalent of a European multiplier effect of profit share on the percentage $(\%)$ change in $\mathrm{AD}$ :

$\left[\frac{\partial Y}{Y}\right]_{15 \times 1}=\left(I_{15 \times 15}-H_{15 \times 15}^{\prime}-W_{15 x 15}\right)^{-1}\left(E_{15 \times 15}+P_{15 \times 15}\right)[\partial \pi]_{15 x 1}$

We calculate the total effects of a simultaneous change in $\pi$ (and consequently on $Y$ ) on private investment/GDP and primary budget balance/GDP as in Appendix A.1.

\section{B.2 Policy 2: Effects of changes in government expenditure-to-GDP ratio}

In order to take into account the simultaneous change in public spending we model the impact of a 1\%-point increase in government expenditure-to-GDP on the percentage (\%) change in GDP of each country as follows:

$\left[\frac{\partial Y}{Y}\right]_{15 x 1}=E g_{15 x 15}\left[\partial \kappa_{g}\right]_{15 x 1}+H^{\prime}{ }_{15 x 15}\left[\frac{\partial Y}{Y}\right]_{15 \times 1}+W_{15 x 15}\left[\frac{\partial Y}{Y}\right]_{15 x 1}$

$E g_{15 \times 15}$ is a matrix, whose diagonal elements is the effect of a change in $\kappa_{g}$ in country $j$ on excess demand $(C+I+N X+G)$ in country $j$ :

$E g_{15 \times 15}=\left[\begin{array}{cccc}\frac{\partial I_{1} / Y_{1}}{\partial \kappa_{g 1}}+\frac{\partial N X_{1} / Y_{1}}{\partial \kappa_{g 1}}+\frac{\partial G_{1} / Y_{1}}{\partial \kappa_{g 1}} & 0 & . & 0 \\ 0 & \cdot & \cdot \\ \cdot & \cdot & \cdot \\ 0 & 0 & . & \frac{\partial I_{15} / Y_{15}}{\partial \kappa_{g 15}}+\frac{\partial N X_{15} / Y_{15}}{\partial \kappa_{g 15}}+\frac{\partial G_{15} / Y_{15}}{\partial \kappa_{g 15}}\end{array}\right]$

where $\frac{\partial I_{i} / Y_{i}}{\partial \kappa_{g i}}$ is defined in equation (A25), $\frac{\partial N X_{i} / Y_{i}}{\partial \kappa_{g i}}$ is defined in equation (A26) and $\frac{\partial G_{i} / Y_{i}}{\partial \kappa_{g i}}$ is defined in equation (A27). 
By solving equation (B3) for $\left[\frac{\partial Y}{Y}\right]_{15 \times 1}$ gives us the equivalent of a European multiplier effect of government expenditure-to-GDP on the percentage (\%) change in AD:

$\left[\frac{\partial Y}{Y}\right]_{15 x 1}=\left(I_{15 x 15}-H^{\prime}{ }_{15 x 15}-W_{15 x 15}\right)^{-1}\left(E g_{15 x 15}\right)\left[\partial \kappa_{g}\right]_{15 x 1}$

We calculate the total effects of a simultaneous change in $\kappa_{g}$ (and consequently on $Y$ ) on private investment/GDP and budget balance/GDP as in Appendix A.2.

\section{B.3 Policy 3: Effects of changes in the tax rate on capital income}

We consider a change in tax policy and hence model the impact of a $1 \%$-point change in the tax rate on capital income:

$\left[\frac{\partial Y}{Y}\right]_{15 x 1}=\operatorname{Etr}_{15 \times 15}\left[\partial t_{r}\right]_{15 x 1}+H_{15 x 15}^{\prime}\left[\frac{\partial Y}{Y}\right]_{15 \times 1}+W_{15 x 15}\left[\frac{\partial Y}{Y}\right]_{15 x 1}$

Etn5x15 is a matrix, whose diagonal elements are the effects of a change in $t_{r}$ in country $j$ on excess demand in country $j$ :

$$
\operatorname{Etr}_{15 \times 15}=\left[\begin{array}{cccc}
\frac{\partial C_{1} / Y_{1}}{\partial t_{r 1}}+\frac{\partial I_{1} / Y_{1}}{\partial t_{r 1}} & 0 & . & 0 \\
0 & \cdot & \cdot & \cdot \\
\cdot & \cdot & \cdot & \cdot \\
0 & 0 & \cdot & \frac{\partial C_{15} / Y_{15}}{\partial t_{r 15}}+\frac{\partial I_{15} / Y_{15}}{\partial t_{r 5}}
\end{array}\right]
$$

where $\frac{\partial C_{i} / Y_{i}}{\partial t_{r i}}$ is defined in equation (A36) and $\frac{\partial I_{i} / Y_{i}}{\partial t_{r i}}$ is defined in equation (A37).

Solving equation (B5) for $\left[\frac{\partial Y}{Y}\right]_{15 x 1}$ gives us the equivalent of a European multiplier effect of a change in $t_{r}$ on percentage $(\%)$ change in $\mathrm{AD}$ :

$\left[\frac{\partial Y}{Y}\right]_{15 \times 1}=\left(I_{15 \times 15}-H_{15 \times 15}^{\prime}-W_{15 \times 15}\right)^{-1}\left(E t r_{15 \times 15}\right)\left[\partial t_{r}\right]_{15 \times 1}$

We calculate the total effects of a simultaneous change in $t_{r}$ (and consequently on $Y$ ) on private investment/GDP and budget balance/GDP as in Appendix A.3.

\section{B.4 Policy 4: Effects of changes in the tax rate on labour income}

Finally, we consider the impact of a $1 \%$-point change in the tax rate on labour income:

$$
\left[\frac{\partial Y}{Y}\right]_{15 \times 1}=E t w 15 \times 15\left[\partial t_{w}\right]_{15 \times 1}+H^{\prime} 15 \times 15\left[\frac{\partial Y}{Y}\right]_{15 \times 1}+W_{15 \times 15}\left[\frac{\partial Y}{Y}\right]_{15 \times 1}
$$


Etw15 15 is a matrix, whose diagonal elements are the effects of a change in $t_{w}$ in country $j$ on excess demand in country $j$ :

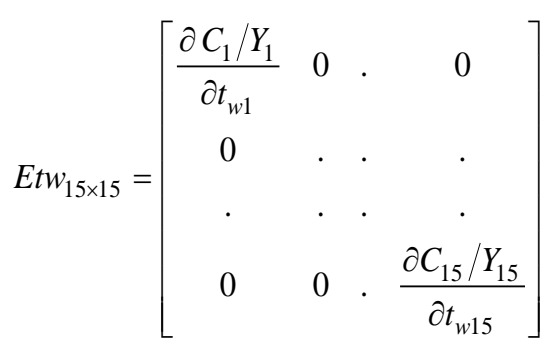

where $\frac{\partial C_{i} / Y_{i}}{\partial t_{w i}}$ is defined in equation (A47).

Solving equation (B7) for $\left[\frac{\partial Y}{Y}\right]_{15 \times 1}$ gives us the equivalent of a European multiplier effect of a change in $t_{w}$ on percentage $(\%)$ change in $\mathrm{AD}$ :

$\left[\frac{\partial Y}{Y}\right]_{15 \times 1}=\left(I_{15 \times 15}-H^{\prime} 15 \times 15-W_{15 \times 15}\right)^{-1} E t w 15 \times 15\left[\partial t_{w}\right]_{15 \times 1}$

We calculate the total effects of a simultaneous change in $t_{w}$ (and consequently on $Y$ ) on private investment/GDP and budget balance/GDP as in Appendix A.4.

\section{B.5 Policy 5: Effects of changes in the tax rate on capital and labour income}

The European multiplier effects of a progressive tax policy based on a $1 \%$-point increase in $t_{r}$ and a $1 \%$-point fall in $t_{w}$ in all countries on equilibrium $\mathrm{AD}$ of each national economy are calculated as follows:

$$
\left[\frac{\partial Y}{Y}\right]_{15 \times 1}=\operatorname{Etn} 5 \times 15\left[\partial t_{w}\right]_{15 \times 1}+E t w 15 \times 15\left[\partial t_{w}\right]_{15 \times 1}+H^{\prime} 15 \times 15\left[\frac{\partial Y}{Y}\right]_{15 \times 1}+W_{15 \times 15}\left[\frac{\partial Y}{Y}\right]_{15 \times 1}
$$

The total European multiplier effect on equilibrium $\mathrm{AD}$ of each country is given by:

$$
\left[\frac{\partial Y}{Y}\right]_{15 x 1}=\left(I_{15 x 15}-H_{15 x 15}^{\prime}-W_{15 x 15}\right)^{-1}\left(\operatorname{Etr}_{15 \times 15}\left[\partial t_{r}\right]_{15 \times 1}+E t w_{15 \times 15}\left[\partial t_{w}\right]_{15 x 1}\right)
$$




\section{Appendix C. Data sources and definitions}

\begin{tabular}{|c|c|c|c|c|}
\hline Symbol & Variable name & Definition & $\begin{array}{l}\text { Source/variable } \\
\text { construction }\end{array}$ & Time period \\
\hline$C$ & $\begin{array}{l}\text { Private consumption } \\
\text { (real) }\end{array}$ & Private final consumption expenditure at constant prices & $\begin{array}{l}\text { AMECO }(2016) \\
\text { (code: } \mathrm{OCPH})\end{array}$ & $1960-2013$ \\
\hline$E$ & Exchange rate & Average of local currency per dollar, euro, and yen & $\begin{array}{l}\text { World Bank World } \\
\text { Development } \\
\text { Indicators }\end{array}$ & $1960-2013$ \\
\hline$G$ & $\begin{array}{l}\text { General government } \\
\text { expenditure }\end{array}$ & $\begin{array}{l}\text { The sum of gross capital formation, individual consumption } \\
\text { expenditure and collective consumption expenditure of the } \\
\text { general government }\end{array}$ & $G=G_{i}+G_{c}+I_{g}$ & $1960-2013$ \\
\hline$G_{c}$ & $\begin{array}{l}\text { Collective consumption } \\
\text { expenditure of general } \\
\text { government }^{1}\end{array}$ & $\begin{array}{l}\text { Expenditures for collective consumption (defence, justice, etc.) } \\
\text { which benefit society as a whole, or large parts of society, and } \\
\text { are often known as public goods and services }\end{array}$ & $\begin{array}{l}\text { OECD, National } \\
\text { Accounts (2016) }\end{array}$ & $1970-2013$ \\
\hline$G_{c e}$ & $\begin{array}{l}\text { General government } \\
\text { consumption } \\
\text { expenditure }\end{array}$ & $\begin{array}{l}\text { General government consumption expenditure, consists of } \\
\text { expenditure incurred by government in its production of non- } \\
\text { market final goods and services (except gross fixed capital } \\
\text { formation) and market goods and services provided as social } \\
\text { transfers in kind }\end{array}$ & $\begin{array}{l}\text { OECD, National } \\
\text { Accounts (2016) }\end{array}$ & $1970-2013$ \\
\hline$G_{i}$ & $\begin{array}{l}\text { Individual consumption } \\
\text { expenditure of general } \\
\text { government }^{1}\end{array}$ & $\begin{array}{l}\text { Expenditures for individual consumption (health care, housing, } \\
\text { education, etc.) that reflect expenditures incurred by government } \\
\text { on behalf of an individual household. This category of } \\
\text { expenditure is equal to social transfers in kind from government } \\
\text { to households and so inchides expenditure by government on } \\
\text { market goods and services provided to households }\end{array}$ & $\begin{array}{l}\text { OECD, National } \\
\text { Accounts (2016) }\end{array}$ & $1970-2013$ \\
\hline$G_{t c}$ & $\begin{array}{l}\text { Final consumption } \\
\text { expenditure of general } \\
\text { government }\end{array}$ & $\begin{array}{l}\text { Final consumption expenditure of general government }= \\
\text { individual consumption of general government }+ \text { collective } \\
\text { consumption of general government }\end{array}$ & $\begin{array}{l}\text { AMECO }(2016) \\
\text { (code: OCTG) }\end{array}$ & $1960-2013$ \\
\hline$I$ & Private investment (real) & $\begin{array}{l}\text { Total investment minus gross capital formation expenditure of } \\
\text { general government }\end{array}$ & $I=I_{t} I_{p r} / I_{\text {tcurr }}$ & $1960-2013$ \\
\hline$I_{g}$ & $\begin{array}{l}\text { Gross capital formation } \\
\text { expenditure of general } \\
\text { government }^{2}\end{array}$ & $\begin{array}{l}\text { Gross fixed capital formation consists of resident producers' } \\
\text { acquisitions, less disposals, of fixed assets during a given period } \\
\text { plus certain additions to the value of non-pro-duced assets } \\
\text { realised by the productive activity of producer or institutional } \\
\text { units. Fixed assets are produced assets used in production for } \\
\text { more than one year. }\end{array}$ & $I_{g}=I_{t}\left(1-I_{p r} / I_{t c u r r}\right)$ & $1960-2013$ \\
\hline$I_{t}$ & Total investment (real) & Gross fixed capital formation at constant prices, total economy & $\begin{array}{l}\text { AMECO (2016) } \\
\text { (code: OIGT) }\end{array}$ & $1960-2013$ \\
\hline$I_{p r}$ & $\begin{array}{l}\text { Private investment } \\
\text { (current prices) }\end{array}$ & Gross fixed capital formation at current prices, private sector & $\begin{array}{l}\text { AMECO (2016) } \\
\text { (code: UIGP) }\end{array}$ & $1960-2013$ \\
\hline$I_{\text {tcurr }}$ & $\begin{array}{l}\text { Total investment } \\
\text { (current prices) }\end{array}$ & Gross fixed capital formation at current prices, total economy & $\begin{array}{l}\text { AMECO (2016) } \\
\text { (code: UIGT) }\end{array}$ & $1960-2013$ \\
\hline$M$ & Imports (real) & Imports of goods and services at constant prices & $\begin{array}{l}\text { AMECO (2016) } \\
\text { (code: OMGS) }\end{array}$ & $1960-2013$ \\
\hline$M_{j i}$ & $\begin{array}{l}\text { Imports from country } j \\
\text { to country } i\end{array}$ & $\begin{array}{l}\text { For each reporting country or group, all the trading partners are } \\
\text { listed }\end{array}$ & $\begin{array}{l}\text { IMF, Direction of } \\
\text { Trade Statistics }\end{array}$ & $1980-2012$ \\
\hline$P$ & GDP deflator & Price deflator gross domestic product at market prices & $\begin{array}{l}\text { AMECO (2016) } \\
\text { (code: PVGD) }\end{array}$ & $1960-2013$ \\
\hline$P_{m}$ & Import price deflator & Price deflator imports of goods and services & $\begin{array}{l}\text { AMECO (2016) } \\
\text { (code: PMGS) }\end{array}$ & $1960-2013$ \\
\hline$P_{x}$ & Export price deflator & Price deflator exports of goods and services & $\begin{array}{l}\text { AMECO (2016) } \\
\text { (code: PXGS) }\end{array}$ & $1960-2013$ \\
\hline$r$ & Interest rate & Real bng-term interest rate & $\begin{array}{l}\text { AMECO (2016) } \\
\text { (code: ILRV) }\end{array}$ & $1960-2013$ \\
\hline$R$ & $\begin{array}{l}\text { Adjusted gross } \\
\text { operating surplus (real) }\end{array}$ & Profit share times output at factor costs & $R=\pi Y_{f}$ & $1960-2013$ \\
\hline rulc & Real unit labour costs & Wage share times output at factor costs over output & rulc $=w Y_{f} / Y$ & $1960-2013$ \\
\hline
\end{tabular}




\begin{tabular}{|c|c|c|c|c|}
\hline Symbol & 1 Variable name & Definition & $\begin{array}{l}\text { Source/variable } \\
\text { construction }\end{array}$ & Time period \\
\hline$t_{c}$ & $\begin{array}{l}\text { Implicit tax rate (ITR) } \\
\text { on consumption }^{3}\end{array}$ & $\begin{array}{l}\text { All consumption taxes divided by the final consumption } \\
\text { expenditure of private households on the economic territory }\end{array}$ & $\begin{array}{l}\text { European } \\
\text { Commission, Eurostat }\end{array}$ & $1965-2012$ \\
\hline$t_{c f}$ & $\begin{array}{l}\text { Implicit tax rate (ITR) } \\
\text { on consumption abroad }\end{array}$ & $\begin{array}{l}\text { Weighted average calculated by multiplying } t_{c} \text { in country } j \text { with } \\
\text { the share of exports (in total exports) of country } i \text { that are } \\
\text { exported to country } j\end{array}$ & & $1965-2012$ \\
\hline$t_{r}$ & $\begin{array}{l}\text { Implicit tax rate (ITR) } \\
\text { on capital }^{4}\end{array}$ & $\begin{array}{l}\text { Revenue from all capital taxes divided by all potentially taxable } \\
\text { business and capital income in the economy }\end{array}$ & $\begin{array}{l}\text { European } \\
\text { Commission, Eurostat }\end{array}$ & 1965-2012 \\
\hline$t_{w}$ & $\begin{array}{l}\text { Implicit tax rate (ITR) } \\
\text { on labour }^{5}\end{array}$ & $\begin{array}{l}\text { Sum of all direct and indirect taxes and employees and } \\
\text { employers social contributions levied on employed labour } \\
\text { income divided by the total compensation of employees working } \\
\text { in the economic territory }\end{array}$ & $\begin{array}{l}\text { European } \\
\text { Commission, Eurostat }\end{array}$ & $1965-2012$ \\
\hline$u l c$ & Unit labour costs & Real unit labour cost times prices & $u l c=r u l c P$ & $1960-2013$ \\
\hline$W$ & $\begin{array}{l}\text { Adjusted compensation } \\
\text { of employees (real) }\end{array}$ & Wage share times outp & $W=w Y_{f}$ & $1960-2013$ \\
\hline$w$ & Adjusted wage share & $\begin{array}{l}\text { Compensation per employee as percentage of GDP at factor } \\
\text { cost per person employed }\end{array}$ & $\begin{array}{l}\text { AMECO (2016) } \\
\text { (code: ALCD0) }\end{array}$ & $1960-2013$ \\
\hline$X$ & Exports (real) & Exports of goods and services at constant prices & $\begin{array}{l}\text { AMECO (2016) } \\
\text { (code: OXGS) }\end{array}$ & $1960-2013$ \\
\hline$X_{j i}$ & $\begin{array}{l}\text { Exports from country } i \\
\text { to country } j\end{array}$ & $\begin{array}{l}\text { For each reporting country or group, all the trading partners are } \\
\text { listed }\end{array}$ & $\begin{array}{l}\text { IMF, Direction of } \\
\text { Trade Statistics }\end{array}$ & $1980-2012$ \\
\hline$Y$ & $\begin{array}{l}\text { GDP in market prices } \\
\text { (real) }\end{array}$ & Gross domestic product at 2010 market prices & $\begin{array}{l}\text { AMECO (2016) } \\
\text { (code: OVGD) }\end{array}$ & $1960-2013$ \\
\hline$Y_{f}$ & $\begin{array}{l}\text { GDP at factor costs } \\
\text { (real) }\end{array}$ & $\begin{array}{l}\text { Gross domestic product at market prices minus taxes on } \\
\text { production and imports, plus subsidies }\end{array}$ & $\begin{array}{l}\text { AMECO (2016) } \\
\text { (code: UYGD) }\end{array}$ & $1960-2013$ \\
\hline$Y_{p}$ & Private demand & Output minus government expenditure & $Y_{p}=Y-G$ & $1960-2013$ \\
\hline$Y_{r w}$ & $\begin{array}{l}\text { GDP of the rest of the } \\
\text { world (real) }\end{array}$ & $\begin{array}{l}\text { Calculated from world GDP (in constant } 2005 \text { US\$) - own } \\
\text { GDP (in constant } 2005 \text { US\$) }\end{array}$ & $\begin{array}{l}\text { World Bank World } \\
\text { Development }\end{array}$ & $1960-2013$ \\
\hline$Y_{w}$ & World GDP (real) & World GDP in constant 2005 US\$ & $\begin{array}{l}\text { World Bank World } \\
\text { Development }\end{array}$ & $1960-2013$ \\
\hline$\kappa_{g}$ & $\begin{array}{l}\text { Government } \\
\text { expenditure-to-GDP } \\
\text { ratio }\end{array}$ & Government expenditure over GDP & $\kappa_{g}=G / Y$ & $1960-2013$ \\
\hline$\pi$ & Adjusted profit share & One minus adjusted wage share & $\pi=1-w$ & $1960-2013$ \\
\hline$\pi^{\prime}$ & $\begin{array}{l}\text { After-tax adjusted profit } \\
\text { share }\end{array}$ & $\begin{array}{l}\text { Adjusted profit share times one minus the tax rate on capital } \\
\text { income }\end{array}$ & $\pi^{\prime}=\left(1-t_{r}\right) \pi$ & $1960-2013$ \\
\hline
\end{tabular}

Notes:

1. OECD data is linked with AMECO online data on General Government Final Consumption Expenditure.

2. Data for Austria starts in 1995 and for Luxembourg in 1990. For Belgium, Denmark, Italy, Ireland, the Netherlands, Spain and Sweden it starts in 1970. We have extended the data back to 1960 in these countries assuming the ratio of general government gross capital formation to total investment stayed constant.

3. For Germany and the UK we have calculated data from 1970 back to 1965 using growth rates based on consumption tax rates provided in the study by Mendoza et al. (1997). For Sweden from 1980 to 1970 . For Austria and Finland from 1980 back to 1965. Data starts only in 1980 in Greece, Portugal and Spain. The tax rates are based on the dataset provided in Eurostat extended by Onaran et al. (2012) which itself draws on the data reported by the European Commission (2000) with data ranging between 1970 and 2007. We extend dataset in Onaran et al. (2012) to 2012 using the growth rate of the data provided by Eurostat (2015).

4. For Luxembourg there is no data on ITR on capital. For Greece, data is not available after 2007 and for Denmark 2012 is unavailable. For Austria and Sweden we have calculated data back from 1970 to 1980, for Germany and the UK from 1965 to 1970, and for Finland from 1965 to 1979 using growth rates based on capital tax rates provided in the study by Mendoza et al. (1997). Data starts only in 1980 in Greece, Portugal, and Spain.

5. For Germany and the UK we have calculated data back from 1970 to 1965, for Austria and Finland from 1980 to 1970 and 1965 respectively, and for Sweden from 1980 to 1970 using growth rates based on labour tax rates provided by Mendoza et al. (1997). Data starts only in 1980 in Greece, Portugal, and Spain. 


\section{Appendix D}

Table D. The effects of a 1\%-point increase in the profit share $(\pi)$ on excess demand

\begin{tabular}{|c|c|c|c|c|c|c|c|c|c|c|c|c|c|c|}
\hline \multirow{2}{*}{$\frac{\text { Consumption }}{\partial(C / Y) / \partial \pi}$} & \multirow{2}{*}{$\frac{\text { Investment }}{\partial(I / Y) / \partial \pi}$} & \multicolumn{8}{|c|}{ Exports } & \multicolumn{4}{|c|}{ Imports } & \multirow{2}{*}{$\frac{\text { Net exports }}{\partial(N X / Y) / \partial \pi}$} \\
\hline & & $e_{P_{u l c}}$ & $1 /\left(1-e_{\text {Pulc }}\right)$ & $\mathrm{e}_{\text {Pxulc }}$ & $e_{\mathbb{P R x}}$ & $e_{\text {Xule }}$ & rulc & $Y_{f} / Y \quad X / Y$ & $\partial(X / Y) / \partial \pi$ & $e_{M P}$ & $e_{\text {Mrulc }}$ & $M / Y$ & $\partial(M / Y) / \partial \pi$ & \\
\hline A & B & C & D & $\mathrm{E}$ & F & $\mathrm{G}=\left(\mathrm{D} * \mathrm{E}^{*} \mathrm{~F}\right)$ & $\mathrm{H}$ & G & $\mathrm{K}=-\left(\mathrm{G}^{*} \mathrm{I}^{*} \mathrm{G} / \mathrm{H}\right)$ & $\mathrm{L}$ & $M=\left(C * D^{*} L\right)$ & $\mathrm{N}$ & $0=-(\mathrm{M} * * N / \mathrm{H})$ & $\mathrm{P}=(\mathrm{K}-0)$ \\
\hline-0.534 & 0.000 & 0.524 & 2.099 & 0.152 & -1.728 & -0.551 & 0.599 & 0.8740 .291 & 0.234 & 0.341 & 0.375 & 0.306 & -0.168 & 0.402 \\
\hline-0.165 & 0.000 & 0.214 & 1.272 & 0.096 & 0.000 & 0.000 & 0.603 & 0.8970 .491 & 0.000 & 0.287 & 0.078 & 0.487 & -0.057 & 0.057 \\
\hline-0.424 & 0.000 & 0.465 & 1.870 & 0.338 & -0.627 & -0.397 & 0.582 & 0.8660 .305 & 0.180 & 0.000 & 0.000 & 0.261 & 0.000 & 0.180 \\
\hline-0.369 & 0.000 & 0.518 & 2.076 & 0.185 & -0.576 & -0.221 & 0.608 & 0.8900 .230 & 0.074 & 0.000 & 0.000 & 0.244 & 0.000 & 0.074 \\
\hline-0.463 & 0.086 & 0.529 & 2.121 & 0.289 & -0.439 & -0.269 & 0.602 & 0.8690 .161 & 0.062 & 0.136 & 0.153 & 0.163 & -0.036 & 0.098 \\
\hline-0.689 & 0.000 & 0.366 & 1.577 & 0.333 & -0.379 & -0.199 & 0.600 & 0.9130 .207 & 0.063 & 0.000 & 0.000 & 0.195 & 0.000 & 0.063 \\
\hline-0.572 & 0.000 & 0.423 & 1.734 & 0.377 & -0.729 & -0.476 & 0.547 & 0.9080 .125 & 0.099 & 0.000 & 0.000 & 0.179 & 0.000 & 0.099 \\
\hline-0.335 & 0.164 & 0.334 & 1.501 & 0.171 & 0.000 & 0.000 & 0.588 & 0.8960 .455 & 0.000 & 0.401 & 0.201 & 0.456 & -0.140 & 0.140 \\
\hline-0.207 & 0.069 & 0.445 & 1.802 & 0.257 & -0.307 & -0.142 & 0.586 & 0.9130 .165 & 0.037 & 0.210 & 0.169 & 0.165 & -0.043 & 0.080 \\
\hline-0.153 & 0.000 & 0.232 & 1.303 & 0.322 & 0.000 & 0.000 & 0.521 & 0.9301 .190 & 0.000 & 0.000 & 0.000 & 0.999 & 0.000 & 0.000 \\
\hline-0.367 & 0.131 & 0.461 & 1.855 & 0.370 & 0.000 & 0.000 & 0.634 & 0.9160 .428 & 0.000 & 0.139 & 0.119 & 0.385 & -0.066 & 0.066 \\
\hline-0.443 & 0.000 & 0.668 & 3.011 & 0.090 & 0.000 & 0.000 & 0.638 & 0.9130 .161 & 0.000 & 0.568 & 1.143 & 0.194 & -0.317 & 0.317 \\
\hline-0.858 & 0.000 & 0.430 & 1.754 & 0.320 & -0.277 & -0.155 & 0.614 & 0.9130 .149 & 0.034 & 0.244 & 0.184 & 0.144 & -0.039 & 0.074 \\
\hline-0.535 & 0.085 & 0.407 & 1.687 & 0.172 & -0.508 & -0.147 & 0.517 & 0.8150 .273 & 0.063 & 0.464 & 0.319 & 0.273 & -0.137 & 0.200 \\
\hline-0.547 & 0.000 & 0.558 & 2.264 & 0.207 & -0.518 & -0.243 & 0.612 & 0.8900 .199 & 0.070 & 0.000 & 0.000 & 0.198 & 0.000 & 0.070 \\
\hline
\end{tabular}

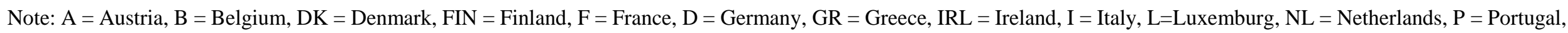
$\mathrm{E}=\mathrm{Spain}, \mathrm{S}=\mathrm{Sweden}, \mathrm{UK}=$ United Kingdom 
${ }^{1}$ EU15 refers to the 15 West European old member states of the EU, which includes the UK despite the Brexit decision. We keep the UK as part of our analysis for Europe, as policy coordination issues discussed in the paper can be implemented even when countries are not part of a political union, although we recognise the importance of a political union to facilitate such policy coordination.

${ }^{2}$ For the potential positive effects of public investment on private investment, see Seguino (2012) and Dutt (2013). For the potential positive effects of government spending on labour productivity, see Commendatore et al. (2011) and Tavani and Zamparelli (2017). In our model we abstract from distinguishing between the long-run and shortrun impact of government spending and from different types of government expenditure on private investment.

${ }^{3}$ The use of the profit rate instead of the profit share would not change the conclusions of our analysis. First, we have econometrically estimated equation (2) using the profit rate and we have found that the results are similar to the specification in which investment depends on the profit share. Second, although the profit rate and the profit share do not always move in the same direction, in our sample, their correlation is high in the vast majority of the countries. The results are available upon request.

${ }^{4} \mathrm{We}$ assume that the government decides about government spending by taking into account the share of government expenditure in output rather than the absolute value of government spending. Dutt (2013) has made a similar assumption about the expenditure on public investment.

${ }^{5}$ In reality, an increase in public spending produces an increase in the wages of the public sector employees, affecting the wage share. For simplicity, we assume away this effect. If this effect was taken into account, an increase in public spending would provide a further boost to economic activity via consumption.

${ }^{6}$ Results are available upon request.

${ }^{7}$ In our econometric estimations, we use the adjusted wage share and the adjusted profit share as provided by AMECO. Compared to the unadjusted wage share, the adjusted wage share takes explicitly into account the role of self-employment. This is done by assigning a certain proportion of the average self-employment income to the average compensation of dependent employees, following the methodology outlined by Gollin (2002). Moreover, the tax rates on labour, capital and consumption are captured by the corresponding implicit tax rates also provided by AMECO. The implicit tax rates of each tax base category are calculated as the ratio of the total tax revenues of the category to the potential tax base of this category. See Appendix C for more details and sources.

${ }^{8}$ Results are available upon request.

${ }^{9}$ When we compare our results to previous findings in the empirical literature (Onaran and Obst, 2016) we find a general breakdown of the profit-investment nexus since the start of the Great Recession in 2007. Taking after-tax profits, this issue becomes even more apparent. Only $5 \mathrm{EU}$ countries have a statistically significant profitability effect.

${ }^{10} \mathrm{We}$ also found negative significant effects for the UK in the full sample 1960-2012 in some specifications. However, when running a robustness check with a reduced sample prior to the crisis (1960-2007) the significant negative effects in the UK do not hold true. Hence, we report the specification where government expenditure is insignificant and dropped from the equation. For Belgium and France the negative effects of government expenditure hold true also in the reduced sample, hence we keep the original estimation.

${ }^{11}$ Results are available upon request.

${ }^{12}$ Estimating a reduced sample size (1960-2007) shows that the perverse effects are driven by the significant reduction of the tax rate on capital from $42 \%$ to $26 \%$ during the crisis period.

${ }^{13}$ Stockhammer et al. (2009) find multipliers ranging between 1.38 and 2.69 for the Euro area.

${ }^{14}$ Onaran and Obst (2016) found a decline in EU15 GDP by $0.30 \%$ following a $1 \%$ fall in the wage share in Europe.

${ }^{15}$ The empirical significance of spill-over effects as well as the importance of coordination of fiscal policies is also confirmed in Auerbach and Gorodnichenko (2013). 